\title{
Molecular detection, quantification, and isolation of Streptococcus gallolyticus bacteria colonizing colorectal tumors: inflammation-driven potential of carcinogenesis via IL-1, COX-2, and IL-8
}

\author{
Ahmed S Abdulamir ${ }^{1,2^{*}}$, Rand R Hafidh¹, Fatimah Abu Bakar ${ }^{1}$
}

\begin{abstract}
Background: Colorectal cancer (CRC) has long been associated with bacteremia and/or endocarditis by Streptococcus gallolyticus member bacteria (SGMB) but the direct colonization of SGMB along with its molecular carcinogenic role, if any, has not been investigated. We assessed the colonization of SGMB in CRC patients with history of bacteremia (CRC-w/bac) and without history of bacteremia (CRC-wo/bac) by isolating SGMB from feces, mucosal surfaces of colorectum, and colorectal tissues and detecting SGMB DNA, via PCR and in situ hybridization (ISH) assays targeting SodA gene in colorectal tissues. Moreover, mRNA of IL1, IL-8, COX-2, IFN- $\gamma, \mathrm{c}-\mathrm{Myc}$, and BCl-2 in colorectal tissues of studied groups was assessed via ISH and RT-PCR.

Results: SGMB were found to be remarkably isolated in tumorous (TU) and non-tumorous (NTU) tissues of CRC$\mathrm{W} / \mathrm{bac}, 20.5 \%$ and $17.3 \%$, and CRC-wo/bac, $12.8 \%$ and $11.5 \%$, respectively while only $2 \%$ of control tissues revealed SGMB (P < 0.05); such contrast was not found in mucosal and fecal isolation of SGMB. The positive detection of SGMB DNA in TU and NTU of CRC-w/bac and CRC-wo/bac via PCR, 48.7\%, 35.9\%, 32.7\%, and 23\%, respectively, and ISH, 46.1\%, 30.7\%, 28.8\%, and 17.3\%, respectively, was higher than in control tissues, 4 and $2 \%$, respectively ( $P<0.05)$. SGMB count measured via quantitative PCR of SGMB DNA in terms of copy number (CN), in TU and NTU of CRC-w/bac and CRC-wo/bac, 2.96-4.72, 1.29-2.81, 2.16-2.92, and 0.67-2.07 $\log _{10}$ CN/g respectively, showed higher colonization in TU than in NTU and in CRC-w/bac than in CRC-wo/bac $(P<0.05)$. The PCR-based mRNA ratio and ISH-based percentage of positively stained cells of IL-1, 1.77 and 70.3\%, COX-2, 1.63 and 44.8\%, and IL-8, 1.73 and $70.3 \%$, respectively, rather than IFN- $\gamma$, c-Myc, and Bcl-2, were higher in SGMB positive patients than in control or SGMB negative patients $(P<0.05)$.

Conclusions: The current study indicated that colorectal cancer is remarkably associated with SGMB; moreover, molecular detection of SGMB in CRC was superior to link SGMB with CRC tumors highlighting a possible direct and active role of SGMB in CRC development through most probably inflammation-based sequel of tumor development or propagation via, but not limited to, IL-1, COX-2, and IL-8.
\end{abstract}

\section{Background}

Colorectal cancer $(\mathrm{CRC})$ is the $4^{\text {th }}$ most common cancer worldwide [1]. Microorganisms were found to be either etiological agents or play a prominent role in the etiology of many types of cancer $[2,3]$. It has been shown that bacterial infections are possibly linked to cancer by

\footnotetext{
* Correspondence: ahmsah73@yahoo.com

'Institute of Bioscience, University Putra Malaysia, 43400 Serdang, Selangor, Malaysia

Full list of author information is available at the end of the article
}

two mechanisms: inflammation and/or formation of carcinogenic metabolites [4]. Therefore, it might be possible to prevent or treat cancer when the infectious source can be identified [5].

One of the bacterial agents associated with cancer is Streptococcus bovis (S. bovis). S. bovis has been found to be important in human health as 25 to $80 \%$ of patients with $S$. bovis bacteremia have also a colorectal tumor and the association of colonic neoplasia with S. bovis endocarditis has been shown to be 18 to $62 \%$ [6-9].

\section{Ciomed Central}


It was shown that $94 \%$ of $S$. bovis bacteremia with colorectal cancer is associated with $S$. bovis biotype I while only $18 \%$ is associated with biotype II [10]. Later, Osawa et al in 1995 [11] proposed a new species resembling $S$. bovis named S. gallolyticus. Interestingly, it was then found that $S$. bovis biotype I and II/2 isolates are in fact Streptococcus gallolyticus (S. gallolyticus) [12]. Accordingly, S. bovis biotype I was replaced by $S$. gallolyticus subspecies gallolyticus and biotype II/2 was replaced by S. gallolyticus subspecies pasterianus and S. gallolyticus subspecies macedonicus [13]. In the current study, these three taxa were referred to as $S$. gallolyticus member bacteria (SGMB) which have been found to be constantly associated with underlying CRC [12].

Several studies conducted in Asia [14-16] found that S. gallolyticus subspecies gallolyticus (S. bovis biotype I) and S. gallolyticus subspecies pasterianus (S. bovis biotype II/2) are the main bacteria associated with colon cancer in Asia. On the other hand, new studies conducted in Germany [17] and Spain [18] found a remarkable association between S. infantiarus coli (S. bovis II/ 1 ) and colon cancer. Despite the geographical variation, S. gallolyticus subspecies gallolyticus remains the main bacterium associated with colon cancer worldwide.

No studies were conducted to assess the colonization of SGMB in the colon by detecting SGMB DNA directly in CRC tumors using advanced molecular assays. Therefore, in the current study, SGMB-specific primers and probes in PCR and in situ hybridization (ISH) assays, respectively, together with the bacteriological isolation of SGMB were pursued to detect/isolate SGMB DNA/ cells from feces, tumors' mucosal surfaces, and tumors' tissues.

Besides, the nature of SGMB association with CRC was studied in this study since this association has not yet been disclosed clearly. Very few studies $[16,19,20]$ were found to elucidate the underlying mechanism of SGMB association with CRC. Some studies proposed that this association is attributed to the access of SGMB to the circulation via disrupted blood vessels in tumor lesions [19]. However, the appearance of new colonic lesions two to four years after the incidence of SGMB bacteremia/endocarditis [21] and the association of SGMB with preneoplsatic adenomas [16] provided evidence that SGMB might not be a consequence of the tumor lesion. Therefore, in an attempt to clarify the possible role of SGMB colonizing colorectal tissues in triggering, promoting, or propagating CRC, we selected six key factors that might be linked to SGMB colonization and CRC development. Accordingly, two key products of NFkB, namely, interleukin (IL) -1 and COX-2, a central immunological regulator of inflammation, IFN$\gamma$, a central oncogenic factor of CRC, c-Myc, an important antiapoptotic factor, $\mathrm{Bcl}-2$, and a potent angiogenic factor, IL-8, were involved. It is well known that the chronic inflammatory reaction in colorectal mucosa has strongly been implicated in the development of CRC and gastric cancer $[19,20]$. And it is also known that $70 \%$ of CRC is associated with overexpression of c-Myc [22] and most CRC cases are associated with increased antiapoptotic action via increased Bcl-2 expression [23]. And SGMB involvement in CRC patients were found to be strongly associated with increased mRNA expression of IL-8 and NFkB in CRC tumors [16].

\section{Results}

\section{Demographic and histopathological features of CRC}

The demographic and histopathological features of CRC patients are shown in Table 1 . The age and sex ratio of CRC patients were found to be not associated with the previous incidence of SGMB bacteremia, namely CRCwo/bac versus CRC-w/bac groups $(P=0.68$ and 0.52 , respecitvley). In addition, CRC staging and tumor grading were also not associated with previous incidence of

Table 1 Demographic and histological characteristics of control subjects and colorectal cancer patients

\begin{tabular}{|c|c|}
\hline \multicolumn{2}{|c|}{ Controls } \\
\hline Mean age (years) & $57.4 \pm 4.7$ \\
\hline Male: female ratio & 1.18: 1 \\
\hline \multicolumn{2}{|c|}{ CRC-wo/bac patients (52 patients) } \\
\hline Mean age (years) & $59.22 \pm 8.18$ \\
\hline Male: female ratio & 1.2: 1 \\
\hline \multirow[t]{5}{*}{ Duke's staging N (\%) } & B1: 7 (13.4) \\
\hline & B2: 7 (13.4) \\
\hline & C1: 9 (17.3) \\
\hline & C2: $12(23)$ \\
\hline & D: 17 (32.6) \\
\hline \multirow[t]{2}{*}{ Tumor differentiation N (\%) } & Grades 1-2: 21 (40.3) \\
\hline & Grades 3-4: 31 (59.6) \\
\hline \multicolumn{2}{|c|}{ CRC-w/bac patients (39 patients) } \\
\hline Mean age (years) & $56.6 \pm 6.7$ \\
\hline Male: female ratio & 1.16: 1 \\
\hline \multirow[t]{5}{*}{ Duke's staging $-\mathrm{N}(\%)$} & B1: 4 (10.2) \\
\hline & B2: $6(15.3)$ \\
\hline & C1: 7 (17.9) \\
\hline & C2: $10(25.6)$ \\
\hline & D: $13(33.3)$ \\
\hline \multirow[t]{2}{*}{ Tumor differentiation N (\%) } & Grades 1-2: 17 (43.5) \\
\hline & Grades 3-4: 22 (56.4) \\
\hline \multicolumn{2}{|c|}{$\begin{array}{l}\text { Localization of tumors in CRC-w/bac and CRC-wo/bac patients (91 } \\
\text { patients) }\end{array}$} \\
\hline Left colon \& rectum -N (\%) & $48 / 91(52.7)$ \\
\hline Rectum only - N(\%) & $15 / 48(31.2)$ \\
\hline Right colon -N (\%) & $31 / 91(34)$ \\
\hline Transverse colon -N (\%) & 12/91 (13.2) \\
\hline
\end{tabular}


SGMB bacteremia, namely CRC-w/bac versus CRC-wo/ bac groups $(P=0.47$ and 0.21 , respectively).

\section{Isolation of SGMB}

The positive detection/isolation of SGMB and S. bovis was found to be mostly impossible without using enrichment media. The positive detection of fecal SGMB was within the normal range, 2.5 to $15 \%$ [24]. The frequency of SGMB isolation from feces and mucosal surfaces of normal tissues in control population was not different $(P=0.4)$. Most importantly, the frequency of isolation of SGMB from feces and mucosal surfaces of TU and NTU lesions in both CRC-wo/bac, and CRC$\mathrm{w} / \mathrm{bac}$ groups was not different from the corresponding control groups $(P=0.77,0.42,0.9,0.71,0.8,0.8$, respectively) (Table 2).

Unlike the samples of feces and mucosal surfaces of colorectum, SGMB isolated from colorectal tissues were much higher in CRC patients than in control group. High percentage of positive isolation of SGMB was associated with TU (20.5\%) and NTU (12.8\%) of CRC-w/bac, and TU (17.3\%) and NTU (11.5\%) of CRC-wo/bac while very low percentage of positive SGMB isolation (2\%) was associated with control group $(P=0.0008,0.013$, $0.0027,0.026$, respectively) (Table 2, Figure 1 ). TU specimens showed close figures of positive isolation of SGMB to that in NTU in both CRC-w/bac $(P=0.18)$ and CRC-wo/bac groups $(P=0.24)$. It is worth mentioning that all CRC patients, whose fecal and mucosal surface samples revealed positive isolation of SGMB, showed also positive isolation of SGMB from colorectal tumor tissues but the opposite was not true.

Regarding S. bovis, the percentage of its positive isolation was minimal in feces and on the surfaces of colorectal mucosa while it was totally absent in colorectal tissues in all groups (Table 2). The findings of API 20 Strep and Rapid ID32 Strep galleries confirmed the results obtained by the bacteriological tests. All the isolates diagnosed bacteriologically as S. gallolyticus from feces, mucosal surfaces, and colorectal tissues were 88 , 90.2, and 94.5\%, respectively, of biotype I whereas the rest of isolates were shown to be of biotype II/2. On the other hand, all the isolates diagnosed as $S$. bovis were shown to be of biotype II/1. Hence, the bacteriological findings indicated that SGMB rather than S. bovis are mainly associated with human bowel and colorectal tissues. And SGMB were within normal percentages in feces or on mucosal surfaces of CRC patients and control group. Nevertheless, SGMB in tumor lesions and safe margins were remarkably found at high levels.

\section{PCR-based detection of SGMB DNA in colorectal tissues}

By gel electrophoresis, it was found that a single band of 408 bp PCR product was visible in all PSBS and PSBStissue samples while it was absent in all NSBS and NSBS-tissue samples (Figure 2). These findings confirmed the specificity of $\operatorname{SodA}$ gene primers for the detection of SGMB DNA mixed with larger quantities of DNA of human tissues or DNA of other bacteria found in human bowel.

Since bacteriological methods revealed significant colonization of SGMB in tumor tissues, but not in feces or on mucosal surfaces, PCR-based detection of SGMB DNA was pursued for colorectal tissues. PCR assay revealed more remarkable results than that of bacteriological assays. It was found that the positive detection of SGMB DNA in CRC-wo/bac TU (32.7\%) and NTU (23\%) tissues was higher than in colorectal tissues of control group (4\%) $(P=0.0005, \mathrm{p}=0.012$, respectively $)$ (Table 3, Figure 1). More strikingly, the positive detection of SGMB DNA in CRC-w/bac TU (48.7\%) and NTU (35.9\%) tissues was far higher than in colorectal tissues of control group (4\%) $(P=<0.0001,0.0003$, respectively) (Table 3, Figure 1). There was no single case where NTU was positive for SGMB DNA while the corresponding TU was negative. However, the frequency of positively detected SGMB DNA in TU versus NTU in both CRC-wo/bac and CRC-w/bac groups was not

Table 2 Bacteriological isolation of SGMB and S. bovis from feces, mucosal surfaces and tissues of colorectum in control, CRC-wo/bac, and CRC-w/bac groups

\begin{tabular}{|c|c|c|c|c|c|}
\hline \multirow[t]{2}{*}{ Group } & \multirow[t]{2}{*}{ Positive isolation of fecal SGMB N (\%) } & \multicolumn{2}{|c|}{$\begin{array}{l}\text { Positive isolation of mucosal SGMB N } \\
(\%)\end{array}$} & \multicolumn{2}{|c|}{$\begin{array}{c}\text { Positive isolation of tissue SGMB N } \\
(\%)\end{array}$} \\
\hline & & TU & NTU & TU & NTL \\
\hline \multicolumn{6}{|c|}{ S. gallolyticus } \\
\hline Control $(N=50)$ & $4(8)$ & $2(4)$ & & $1(2)$ & \\
\hline CRC-wo/bac $(\mathrm{N}=52)$ & $5(9.6)$ & $4(7.6)$ & $2(3.8)$ & $9(17.3)$ & $6(11.5$ \\
\hline CRC-w/bac $(N=39)$ & $4(10.2)$ & $2(5.1)$ & $2(5.1)$ & $8(20.5)$ & $5(12.8$ \\
\hline \multicolumn{6}{|c|}{ S. bovis } \\
\hline Control $(N=50)$ & $2(4)$ & $1(2)$ & & $0(0)$ & \\
\hline CRC-wo/bac $(\mathrm{N}=52)$ & $2(3.8)$ & $1(1.9)$ & $1(1.9)$ & $0(0)$ & $0(0$ \\
\hline CRC-w/bac $(N=39)$ & $1(2.5)$ & $0(0)$ & $0(0)$ & $0(0)$ & $0(0$ \\
\hline
\end{tabular}




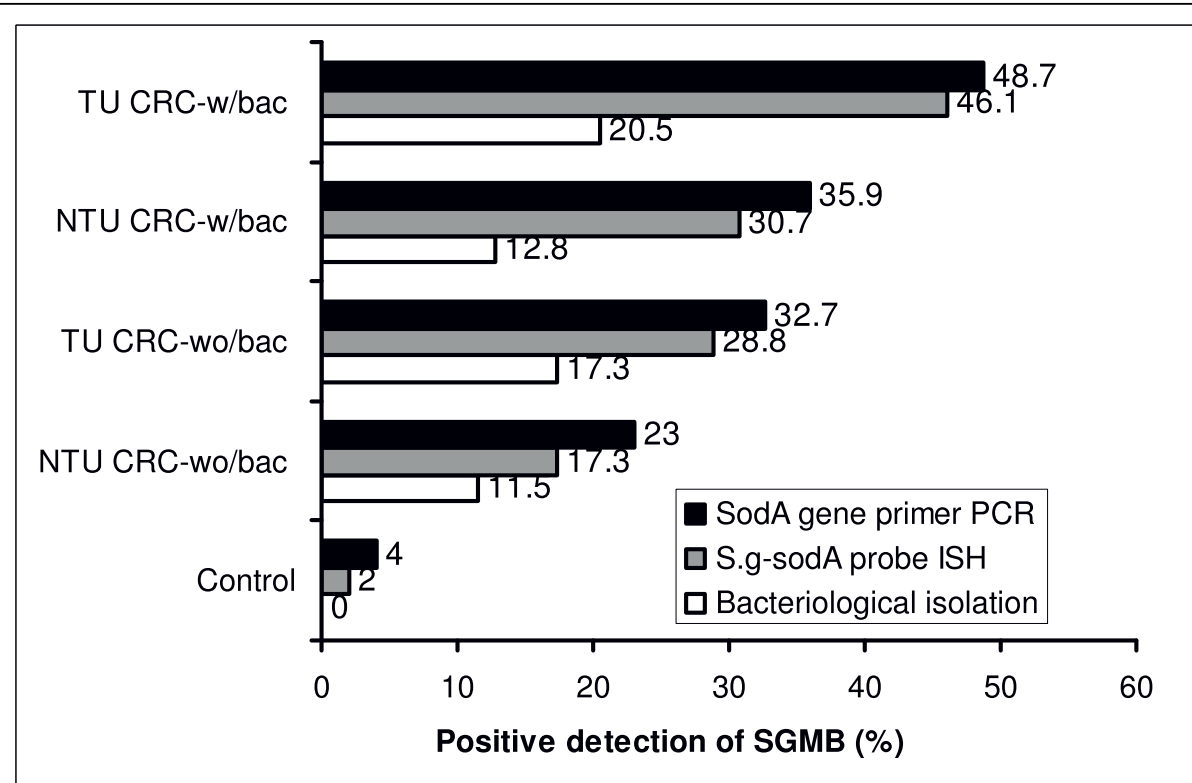

Figure $1 \mathrm{~A}$ histogram showing a comparison in the percentage of the positive detection/isolation of SGMB among control, TU and NTU tissues of CRC-wo/bac, and TU and NTU tissues of CRC-w/bac groups using three detection methods, namely SodA gene primer PCR, S.g-sodA-probe ISH assay, and enrichment-based bacteriological methods. It is shown that the top SGMB detection method was PCR, then ISH assay, and least effective was bacteriological isolation.

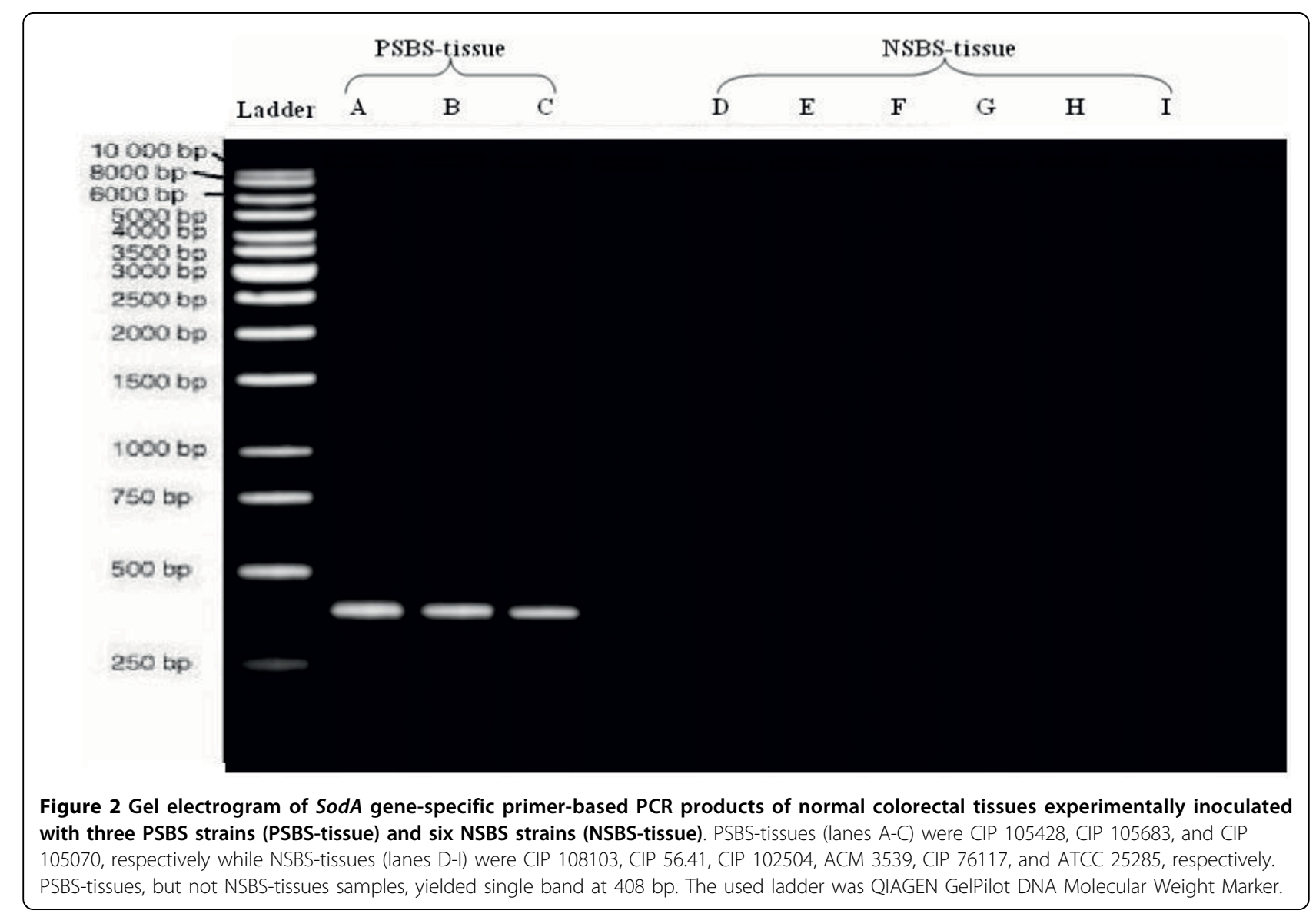


Table 3 Detection of SGMB DNA using PCR assay of SodA gene-specific primer in colorectal tissues of control, CRCwo/bac, and CRC-w/bac groups

\begin{tabular}{ccccc}
\hline Control (N = 50) N (\%) & \multicolumn{2}{c}{ CRC-wo/bac } & \multicolumn{2}{c}{$\begin{array}{c}\text { CRC-w/bac (N = 39) } \\
\mathbf{N}(\mathbf{N}=\mathbf{5 2})\end{array}$} \\
\hline & TU & $\mathbf{N T U}$ & TU & $\mathbf{N T U}$ \\
$2(4)$ & $17(32.7)$ & $12(23)$ & $19(48.7)$ & $14(35.9)$ \\
\hline
\end{tabular}

different $(P=0.22,0.25$, respectively). Moreover, no significant association was found of the frequency of positively detected SGMB DNA, in both TU and NTU, between CRC-wo/bac versus CRC-w/bac $(P=0.12,0.18$, respectively) (Table 3 , Figure 1 ). It is worth mentioning that the positive detection of SGMB by PCR was not associated with stage, grade, and location of tumors ( $P=0.13,0.29,0.48$, respectively) or age and sex of patients $(P=0.41,0.22$, respectively).

\section{ISH-based detection of SGMB DNA in colorectal tissues}

The positive detection of SGMB DNA via ISH assay was achieved by visualizing SGMB as stained chains of tiny spots scattered in tissue sections. The positive staining was rarely seen as aggregations of stained spots or individually scattered spots. S.g-sodA probe of ISH assay yielded positive results in all PSBS-tissue sections, in duplicates, while all the duplicates of NSBS-tissue sections were shown to be negative. Hence, these results provided evidence on the high specificity of S.g-sodA probe.

No characteristic localization or distribution of the stained SGMB DNA was found throughout the tested sections. Instead, stained chains of tiny spots were shown to be scattered in tissue sections. SGMB DNA staining in CRC-wo/bac TU (28.8\%) and NTU (17.3\%) tissues was higher than in colorectal tissues of control group (2\%) ( $P=0.0001,0.015$, respectively) (Table 4, Figure 1) and it was far higher in CRC-w/bac TU (46.1\%) and NTU (30.7\%) tissues than in colorectal tissues of control group $(2 \%)(P=<0.0001,0.0001$, respectively) (Table 4 , Figure 1 ). There was no single case where NTU was positive for SGMB DNA while the corresponding TU was negative. However, the frequency of positive staining of SGMB DNA in TU versus NTU in both CRC-wo/bac and CRC-w/bac groups was not different $(P=0.16,0.16$, respectively $)$ and no significant

Table 4 Detection of SGMB DNA using S.g-sodA probebased ISH assay in colorectal tissue sections of control, CRC-wo/bac, and CRC-w/bac groups

\begin{tabular}{|c|c|c|c|c|}
\hline \multirow[t]{2}{*}{ Control $(\mathrm{N}=50) \mathrm{N}(\%)$} & \multicolumn{2}{|c|}{$\begin{array}{c}\text { CRC-wo/bac } \\
(\mathrm{N}=52) \mathrm{N}(\%)\end{array}$} & \multicolumn{2}{|c|}{$\begin{array}{c}\text { CRC-w/bac } \\
(\mathrm{N}=39) \mathrm{N}(\%)\end{array}$} \\
\hline & TU & NTU & TU & NTU \\
\hline $1(2)$ & $15(28.8)$ & $9(17.3)$ & $18(46.1)$ & $12(30.7)$ \\
\hline
\end{tabular}

association was found in the positive staining of SGMB DNA, in TU and NTU, between CRC-wo/bac versus CRC-w/bac groups $(P=0.09,0.13$, respectively $)$ (Table 4, Figure 1). Since $\operatorname{SodA}$ gene primers have been shown to be highly specific for SGMB, it was considered as a golden standard for S.g-sodA probe- based ISH assay. Accordingly, the sensitivity and specificity of S.g-sodA probe- based ISH assay was 91.6 and $100 \%$, respectively, for TU tissue sections and 87 and 100\%, respectively, for NTU tissue sections. Hence, S.g-sodA probe has been shown to be as specific as PCR assay but with lower sensitivity. Like PCR, the positive detection of SGMB by ISH was not associated with stage, grade, and location of tumors $(P=0.25,0.11,0.38$, respectively) or age and sex of patients $(P=0.26,0.14$, respectively).

\section{Quantification of SGMB DNA in colorectal tissues}

Based on the positive detection of SGMB DNA, the patients and controls of the current study were categorized into two groups, SGMB+ve and SGMB-ve. For $\mathrm{SGMB}+$ ve group, quantitative evaluation of SGMB colonization was sought. The number of bacterial cells, in terms of $\log _{10} \mathrm{CN} / \mathrm{g}$, was compared among colorectal tissues of the studied groups. First of all, the quantitative real-time PCR confirmed the findings of the conventional PCR without any variation. Above all, the quantitative real-time PCR was successful in quantifying SGMB in colorectal tissues of the studied groups. SGMB load in CRC tissues was expressed as 95\% CI of mean $\log _{10} \mathrm{CN} / \mathrm{g}$ (Table 5). The SGMB load in TU and NTU of SGMB+ve-CRC-w/bac and TU, but not NTU, of SGMB+ve-CRC-wo/bac was higher than that of SGMB+ve-control group $(P=<0.000,0.042,0.03,0.07$, respectively). And the difference in SGMB load between TU and NTU, in both SGMB+ve-CRC-wo/bac and SGMB+ve-CRC-w/bac groups, was significant $(P=0.01$, 0.004 , respectively). Moreover, SGMB load in TU, but not NTU, in SGMB+ve-CRC-w/bac was higher than that in SGMB+ve-CRC-wo/bac $(P=0.012,0.2$, respectively). On the other hand, upon conducting the quantitative real-time PCR, melting curve analysis of the negative first derivative was pursued. It was found that a

Table 5 SGMB load in different groups of CRC tissues, SGMB+ve- control, CRC-wo/bac, and CRC-w/bac by using quantitative real-time SodA gene-specific PCR

\begin{tabular}{ccccc}
\hline $\begin{array}{c}\text { SGMB+ve- control } \\
\mathbf{9 5 \%} \mathrm{Cl} \\
\left(\log _{\mathbf{1 0}} \mathrm{CN} / \mathbf{g}\right)\end{array}$ & $\begin{array}{c}\text { SGMB+ve- CRC-wo/bac } \\
\mathbf{9 5 \% C l}\left(\log _{10} \mathrm{CN} / \mathbf{g}\right)\end{array}$ & $\begin{array}{c}\text { SGMB+ve- CRC-w/bac } \\
\mathbf{9 5 \% C l}\left(\log _{10} \mathrm{CN} / \mathbf{g}\right)\end{array}$ \\
\hline$(\mathrm{N}=2)$ & $\mathrm{TU}$ & $\mathrm{NTU}$ & $\mathrm{TU}$ & $\mathrm{NTU}$ \\
& $(\mathrm{N}=17)$ & $(\mathrm{N}=12)$ & $(\mathrm{N}=19)$ & $(\mathrm{N}=14)$ \\
& & & & \\
$0.48-1.44$ & $2.16-2.92$ & $0.67-2.07$ & $2.96-4.72$ & $1.29-2.81$ \\
\hline
\end{tabular}


single peak at the expected melting temperature of PCR product, $\mathrm{Tm} 84.3^{\circ} \mathrm{C}$, was observed while no significant premature peaks were seen indicating that primer dimers were minimal which provides further evidence on the specific detection of SGMB.

\section{The mRNA expression of IFN- $\gamma$, COX-2, IL-1, IL-8, c-Myc, and $\mathrm{Bcl}-2$}

The comparative results of mRNA level of the studied cytokines and oncogenes among the involved groups of CRC patients and control subjects were very similar in both semi-quantitative real-time RT-PCR, in term of mRNA ratio, and in ISH assay, in term of percentage of the positively stained cells. For $\mathrm{C}-\mathrm{Myc}$ and $\mathrm{Bcl}-2$, the mRNA expression was higher in TU, but not NTU, of CRC patients than of control group and higher in TU than in NTU in all CRC groups; nevertheless, no significant difference was found in the level of mRNA expression of $\mathrm{c}-\mathrm{Myc}$ and $\mathrm{Bcl}-2$ regarding the history of bacteremia or the positive detection of SGMB (Figure 3 and 4). For IL-8, mRNA level was higher in TU than in NTU in all groups of CRC patients; IL-8 mRNA was higher in TU and NTU of SGMB+ve groups in both CRC-w/bac and CRC-wo/bac than in SGMB-ve groups; and IL-8 mRNA was higher in TU and NTU of SGMB +ve, but not SGMB-ve, in both CRC-w/bac and CRCwo/bac than in control group (Figure 3 and 4 ). On the other hand, the mRNA level of proinflammatory cytokines, IL-1 and COX-2, was at close levels between TU and NTU of all CRC groups; it was significantly higher in TU and NTU of SGMB+ve than in SGMB-ve groups in both $\mathrm{CRC}$-w/bac and CRC-wo/bac; and it was higher in TU and NTU of SGMB+ve, but not SGMB-ve, groups than in control group (Figure 3 and 4). Regarding IFN- $\gamma$, the mRNA level was not significantly different between TU and NTU in all CRC groups, between SGMB+ve and SGMB-ve groups in both CRC-w/bac and CRC-wo/bac, and between control and all CRC groups (Figure 3 and 4). Accordingly, the mRNA expression of the studied agents revealed that inflammatory cytokines, IL-1 and COX-2, were strongly associated with SGMB colonization more than transformation process itself while mRNA expression of IFN- $\gamma$ was not shown to be related significantly with transformation, SGMB, or TU versus NTU. On the contrary, the mRNA expression of oncogenic and antiapoptotic factors, $\mathrm{c}-\mathrm{Myc}$ and $\mathrm{Bcl}-2$, was associated with the transformation process but not with SGMB colonization or safe margin tissues, namely NTU. Interestingly, IL- 8 proved to be of vital role in the carcinogenesis of colorectal tissues; mRNA expression of IL-8 was associated strongly with SGMB colonization, transformation process, and TU versus NTU tissues. It is worth mentioning that mRNA level in either ISH assay or semi- quantitative RT-PCR was not associated with age and sex of CRC patients or with CRC stage, tumor grade, or location of tumors. However, the mean mRNA ratio and percentage of positively stained cells of Bcl-2 in B1, B2, $\mathrm{C} 1$, and $\mathrm{C} 2$ stages collectively, $0.84 \pm 0.23$ and $21.6 \pm$ $6.2 \%$ were much lower than in advanced D stage, $1.35 \pm$ 0.12 and $58 \pm 7.2$, respectively $(P=0.01,0.008$ respectively).

\section{Correlations among mRNA expression of cytokines and with SGMB load}

The mRNA ratio of IL-1 was positively correlated with that of COX-2 in TU SGMB+ve-CRC-wo/bac ( $\mathrm{r}=+0.85, P=0.002)$ and in TU SGMB+ve-CRC-w/bac ( $\mathrm{r}=+0.78, P=0.003)$. The mRNA ratio of IL- 8 was positively correlated with that of COX-2 in TU SGMB + ve-CRC-w/bac $(\mathrm{r}=+0.86, P=0.001)$ and, to a lesser extent, in TU SGMB+ve-CRC-wo/bac $(\mathrm{r}=+0.77$, $P=0.016)$.

One of the interesting findings, though might be predicted from the earlier results of the current study, the bacterial load of SGMB, in terms of $\log _{10} \mathrm{CN} / \mathrm{g}$, was positively correlated with mRNA ratio of IL- 8 in TU SGMB+ve-CRC-w/bac $(\mathrm{r}=+0.82 .3, P=0.01)$ and TU $\mathrm{SGMB}+$ ve-CRC-wo/bac $(\mathrm{r}=+0.74, P=0.02)$, COX-2 in TU SGMB+ve-CRC-w/bac $(\mathrm{r}=+0.83, P=0.004)$, and IL- 1 in TU SGMB+ve-CRC-w/bac $(r=+0.78, P=$ 0.01). Collectively, all positive correlations were observed among IL-1, COX-2, and IL-8 in TU SGMB +ve sections; moreover, the mRNA expression of these three cytokines, rather than other studied agents, was positively correlated with SGMB load in colorectal tissues. This confirmed the earlier findings which pointed out clearly to the remarkable association of IL-8, COX-2 and IL-1 with SGMB colonization of colorectal tumors.

\section{Discussion}

The association of SGMB, previously known as S. bovis, with CRC has been reported to be 18 to $62 \%$ [6-9]. Hence, Beeching et al proposed that all patients with SGMB bacteremia/endocarditis should be rigorously investigated for the presence of a colonic tumor [25]. However, the association of SGMB with CRC has always been described through the incidence of SGMB bacteremia and/or endocarditis. Little research has been done on elucidating the direct relationship of SGMB with tumor lesions of CRC to confirm or refute, on solid bases, the direct link between CRC and SGMB.

In the current study, the association of SGMB with CRC was confirmed by using biochemical tests, bacteriological isolation of SGMB, and detection of SGMB DNA via PCR and ISH assay at tumor lesions compared to normal colorectal tissues. 

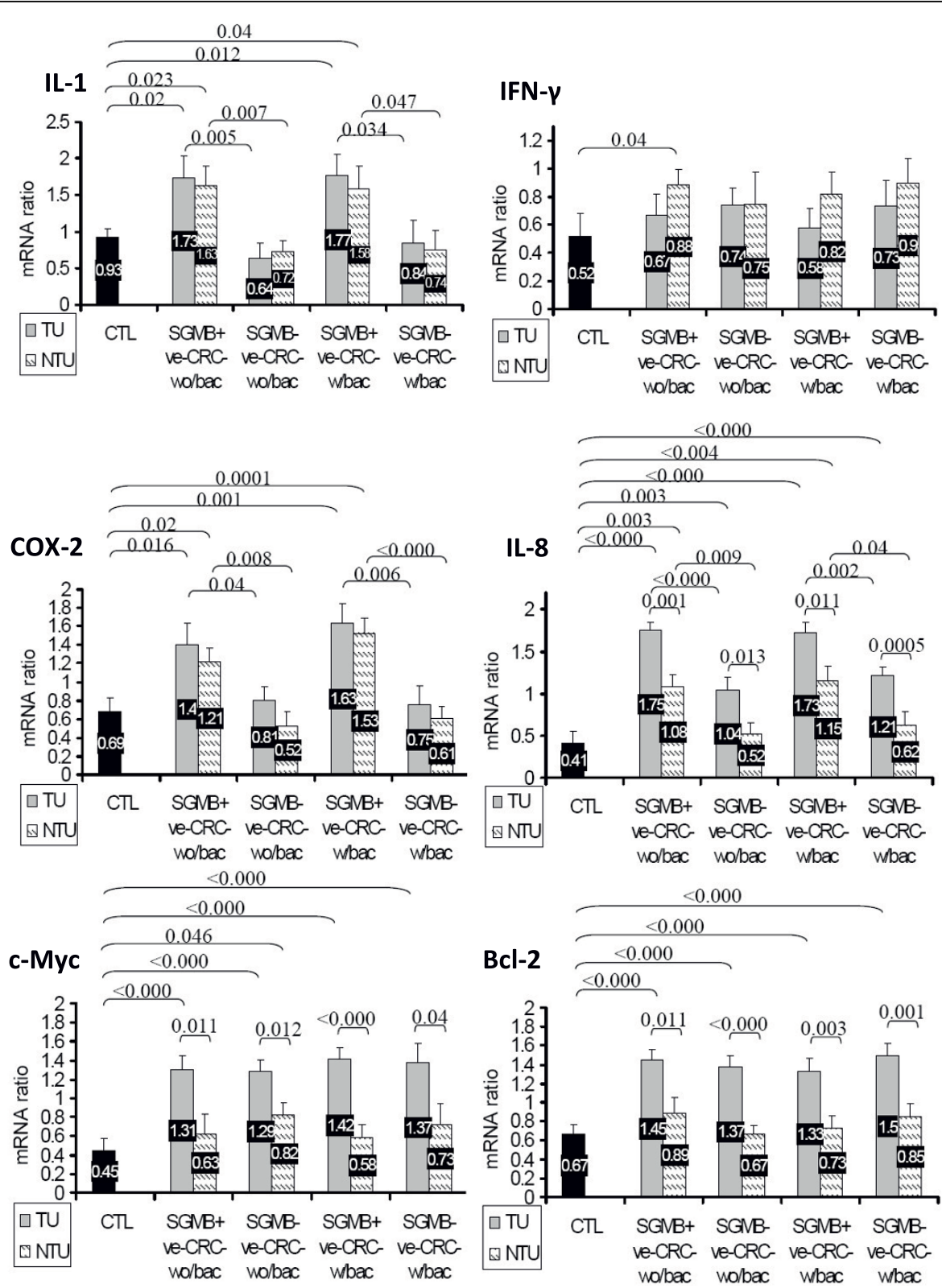

Figure 3 Normalized mRNA ratio, expressed as mean+ SE, of IL-1, IFN- $\gamma$, COX-2, IL-8, c-Myc, and Bcl-2 is shown in TU and NTU tissues of control, SGMB+ve-CRC-wo/bac, SGMB-ve-CRC-wo/bac, SGMB+ve-CRC-w/bac and SGMB-ve-CRC-w/bac. Significant differences in mean mRNA ratio $(P<0.05)$ among different groups are shown as demarcation brace lines with corresponding $P$ values whereas insignificant differences are devoid of demarcation and $P$ values.

SodA gene primer- based PCR and S.g.SodA probebased ISH assay were used. Although PCR assay proved to be more sensitive than ISH, both assays yielded very close findings. PCR and ISH assays succeeded in detecting SGMB in colorectal TU and NTU tissues of CRC patients much higher than in control tissues and fairly higher, about two folds, than in the same tissues by using bacteriological approach. In addition, quantitative real-time PCR revealed significantly higher SGMB colonization in the tissues of SGMB+ve CRC patients than in control group, in TU than in NTU tissues, and in SGMB+ve-CRC-w/bac than in SGMB+ve-CRC-wo/bac groups.

The current findings of bacteriological and molecular assays provided invaluable clues and new facts. First, the bacteriological isolation of SGMB without enrichment media was unsuccessful. With enrichment media, SGMB were isolated in half of the colorectal tissues where SGMB were detected by molecular assays. Almost all of the previous studies explored SGMB colonization in 

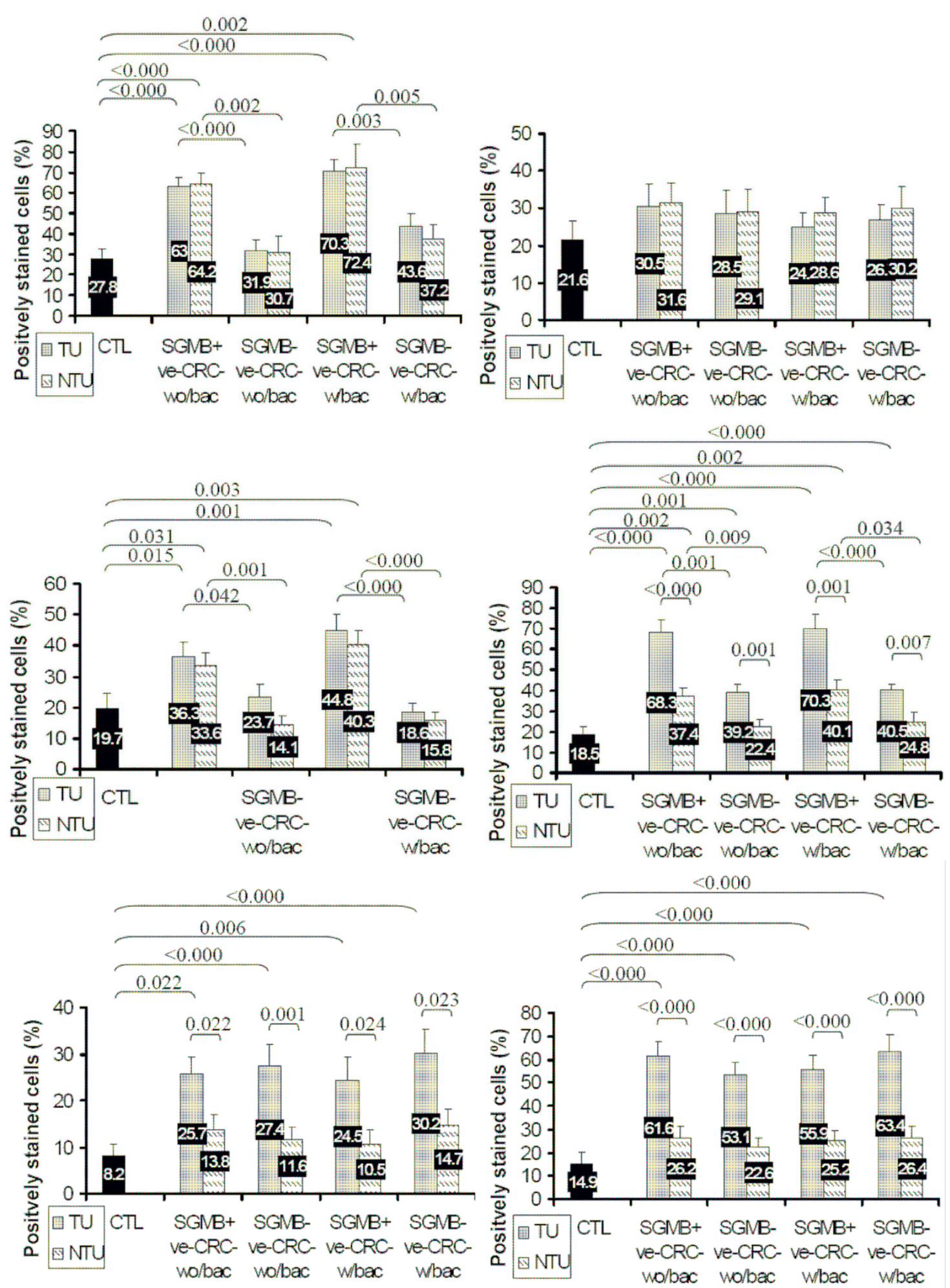

Figure 4 Mean+SE of positive mRNA staining via ISH assay for IL-1, IFN- $\gamma$, COX-2, IL-8, c-Myc, and Bcl-2 is shown in TU and NTU tissues of control, SGMB+ve-CRC-wo/bac, SGMB-ve-CRC-wo/bac, SGMB+ve-CRC-w/bac and SGMB-ve-CRC-w/bac. Significant differences in mean of positive mRNA staining $(P<0.05)$ among different groups was shown as demarcation brace lines with corresponding $P$ values whereas insignificant differences were devoid of demarcation and $\mathrm{P}$ values. 
colorectum were conducted by using simple bacteriological assays without using proper enrichment media and, above all, they did not use molecular assays targeting SGMB DNA. This explains why previous studies found either no evidence of SGMB colonization at tissues of colorectal carcinomas [26] or low colonization percentage, $11 \%$, which was not significantly different from that of mucosal $5.5 \%$, or stool, $11 \%$, samples [27].

The second essential clue of this study, the positive detection of SGMB was confined only to TU and NTU tissues of CRC patients rather than colorectal tissues of control subjects. And the SGMB load, $\log _{10} \mathrm{CFN} / \mathrm{g}$, was significantly higher in TU than in NTU colorectal tissues. These findings suggest that there might be certain kind of host-bacteria interaction involving both transformed and adjacent histologically-normal tissues, and this host-bacteria interaction could be of etiological role in the carcinogenesis of CRC or of propagating factor in tumor development. Klein et al stated that undefined physical or biochemical factors in CRC tissues may encourage $S$. bovis to be locally carcinogenic [28]. In a study using animal models, the cell wall antigens of $S$. bovis were found to promote premalignant lesions through the increased formation of hyper-neoplastic aberrant colonic crypts [19]. Moreover, S. bovis has been shown to be able of causing a longstanding presence in the bowel leading to chronic inflammation in the colon [20]. Accordingly, such chronic bacterial infection/ inflammation may, in turn, contribute to cancer development. In addition, it was also suggested that carcinogenesis might issue when bacterial components interfere with cell function [20].

The third essential clue of this study is that the proven colonization of SGMB in TU and NTU tissues of CRC patients could explain why SGMB, more than other dominant intestinal bacteria, can get access through blood vessels into the circulation which in turn leads to bacteremia and/or endocarditis. This interpretation, which was based on the findings of the current study, supports what was suggested by other studies that colonic lesions provide a suitable microenvironment for $S$. bovis resulting in silent tumor-associated infections which become apparent when cancer patients become immunocompromised, like in bacteraemia, or have coincidental cardiac valve lesions, like in endocarditis $[16,24,25,29]$. In addition, CRC patients with history of bacteremia showed higher frequency of SGMB positive detection as well as higher titer of colonizing SGMB than those without history of bacteremia which provided evidence why some CRC patients develop bacteremia while others do not. Nevertheless, in the current study, SGMB were not detected or isolated in a portion of CRC patients with history of bacteremia. This could be explained that SGMB in some $\mathrm{CRC}-\mathrm{w} / \mathrm{bac}$ patients might be wiped out by antibiotic treatment during bacteremia/endocarditis phase or there might be individual variation among CRC patients in their immunological response to $\mathrm{SGMB}$ bacteremia leading to the eradication of SGMB in some patients and the survival of SGMB in others.

The fourth clue of this study, the colonization of SGMB in CRC tumors and safe margin tissues rather than normal tissues indicated that SGMB might possess peculiar adhesive potential to malignant and premalignant colorectal tissues. The findings of other studies might explain the results of the current study. A study found that $S$. bovis common antigen has the ability to facilitate tumor attachment before translocation to the bloodstream [30]. In addition, a histone-like protein A in S. gallolyticus was found to bind this bacteria tightly to colon tumor cell lines HCT116 and HT-29 [31]. Moreover, Sillanpaa team found that S. gallolyticus has a distinctive ability to bind to all types of collagen proteins in the extra-cellular matrix making S. gallolyticus subspecies gallolyticus a successful colonizer in both intestinal and cardiac tissues which might explain the association between endocarditis and intestinal lesions caused by this bacterium [32].

The fifth essential outcome of the current study is that both $\operatorname{SodA}$ gene-specific primers and probe were successfully used in PCR and ISH assays, respectively, for designing highly sensitive detection tools for SGMB colonizing colorectal tissues. Besides, the detection of SGMB DNA showed that how extensively these bacteria are involved in CRC disease and how the active role of SGMB association with CRC have long been underestimated because of the lack of using sensitive molecular methods of detection.

To disclose the underlying nature of SGMB colonization in colorectal tumors, mRNA expression of six cytokines, chemokines and oncogenes were studied via two different assays, ISH and semi-quantitative real-time RT-PCR. Both assays turned out very similar patterns of mRNA expression. Remarkably high mRNA expression of two proinflammatory cytokines, IL-1 and COX-2, was highly associated with SGMB+ve CRC patients equally in both TU and NTU tissues while their level in SGMBve CRC patients was low and close to that in control group. This granted a peerless chance to highlight the inflammatory potential of SGMB in colorectal tissues. This finding supports the hypothesis that SGMB exert chronic inflammatory reaction in bowel tissues which might be one of the main factors for promoting or propagating the development of malignant or premalignant lesions. These findings are in agreement with Ellmerich study which showed that in vitro binding of $S$. bovis wall extracted antigens to various cell lines stimulated the production of inflammatory cytokines by those cells 
[33]. Moreover, it was stated that the production of inflammatory cytokines in response to $S$. bovis including IL- $1 \beta$, TNF- $\alpha$, and IL- 6 as well as the chemokine IL- 8 plays an important role in the normal defense mechanisms of the host [34] resulting in the production of nitric oxide and free radicals such as superoxide, peroxynitrites and hydroxyl radicals [35]. Due to their remarkable mutagenicity, these molecular species might contribute to the neoplastic processes by modifying cellular DNA.

Regarding the angiogenic chemokine, IL-8, it proved to be exclusively essential in CRC, in general, and SGMB-related CRC, in particular. The level of mRNA expression of IL-8 was higher in SGMB+ve than in SGMB-ve groups, higher in TU than in NTU groups, and higher in CRC than in control groups. In other words, IL-8 was shown to be associated with SGMB colonization, transformation process, and local tumorogenesis altogether. This finding renders IL-8 as the most important link between SGMB and carcinogenesis of CRC. Jung et al showed that IL-8 was the most remarkable chemokine expressed by human colon epithelial cells when exposed to invasive strains of $H$. pylori bacteria [36]. Moreover, it was shown that IL-8 production was induced by CRC cells exposed in vitro to Clostridium difficile toxin A [37]. Interestingly, S. bovis were previously shown to increase the production of IL-8 and, to a lesser extent, inflammatory cytokines in the colonic mucosa of rats, suggesting direct interactions between $S$. bovis and the colonic mucosal cells via IL-8 [33]. Therefore, IL-8 seems to be strongly related to tumorogenesis when is induced or promoted by microbial-driven inflammation. Because of the fact that IL-1 and COX-2 are products of NFkB activity [38], the current findings regarding the association of IL-1, COX-2, and IL- 8 with SGMB+ve CRC confirmed the findings of a previous study conducted by our team where S. gallolyticus-seropositive CRC patients were significantly associated with higher mRNA expression of both NFkB and IL-8 [16]. In addition, it was shown in the current study that COX-2 was positively correlated with IL-1 and IL-8; moreover, IL-1, COX-2, and IL-8 were all positively correlated with SGMB load in TU SGMB+ve CRC patients. This provided extra evidence for the integrative role of IL-1, COX-2, and IL-8 in SGMB-related carcinogenesis of CRC. Hence, these cytokines and chemokines most probably act together by perpetuating the SGMB-induced inflammation along with preparing a strong angiogenic environment which is necessary for the development and expansion of tumors.

For the mRNA expression of the oncogene c-Myc and antiapoptotic Bcl-2, they were not associated with SGMB colonization but were associated with CRC transformation. This might imply that SGMB could have nothing to do with inducing oncogenic changes or suppressing cellular apoptosis. Therefore, SGMB more probably act as a propagator factor for premalignant or oncogene-positive tissues to enter the transformation cycle through inflammatory and angiogenic microclimates. However, this has not yet been confirmed and further studies are needed to assess whether SGMB act as carcinogenic or propagator factors for CRC development. On the other hand, the immunological regulator of inflammation, IFN- $\gamma$, was not related with SGMB or the transformation process of CRC. This might be attributed to the immunosuppressive environment of tumors that rendered IFN- $\gamma$ of equivocal effect on SGMB colonization and CRC carcinogenesis.

\section{Conclusions}

Taken together, the current study showed clearly that the colonization of SGMB do exist in TU and NTU tissues of CRC patients, with or without history of bacteremia, while no such colonization was found in colorectal tissues of control subjects suggesting an active role of SGMB in CRC development. Besides, SGMB colonization was heaviest in TU then in NTU and in CRC-w/ bac then in CRC-wo/bac highlighting that SGMB load might be the main determinant for developing SGMB bacteremia. Moreover, fecal and mucosal SGMB were shown not to reflect reliably the status of SGMB colonization in colorectal tissues. On the contrary, molecular assays detecting SGMB-specific SodA gene, via ISH and PCR, proved to be reliable and much more sensitive than bacteriological approaches. On the other hand, SGMB colonizing colorectum appeared to induce mRNA expression of proinflammatory cytokines, IL-1 and COX-2, as well as angiogenic chemokine, IL-8; these cytokines and chemokines collectively provide bases for promoting/propagating normal or premalignant colorectal tissues into malignant status. It is recommended to conduct further studies to clarify the active role of SGMB in CRC development and pinpoint the molecules in colorectal cells that interact with SGMB leading to such active and, most probably, carcinogenic kind of bacterial colonization.

\section{Methods}

\section{Population of the study}

The involved CRC patients were selected from several gastroenterology centers in the state of Selangor, Malaysia from February 2007 to July 2009. CRC patients were subjected to surgical resection of colorectal cancer and were categorized into two groups, CRC patients with a history of S. gallolyticus/bovis bacteremia in the last 2 years, named as CRC-w/bac, and CRC patients without bacteremia/endocarditis, named as CRC/wo-bac. However, antibiotics taken at the time of bacteremia/ 
endocarditis might still be interfering with the results of the study; therefore, the patients of $\mathrm{CRC}$-w/bac group included in this study were those who were treated from bacteremia/endocarditis by intravenous antibiotics, at least 3 months before conducting surgery in order to minimize antibiotic-driven effect on SGMB colonization, if any. Fifty two CRC-wo/bac, 29 men and 23 women aged between 45 to 78 years and $39 \mathrm{CRC}-\mathrm{w} / \mathrm{bac}$, 21 men and 18 women, aged between 42 to 81 years with primary colorectal adenocarcinoma were involved in the current study before administration of chemotherapy. CRC patients were examined and their health records were reviewed. The patients who revealed no major illness or gastrointestinal disorder other than $\mathrm{CRC}$ and did not receive any antibiotic for the last 3 months, including $\mathrm{CRC}-\mathrm{w} / \mathrm{bac}$, were only recruited in the current study. On the other hand, 50 age- and sexmatched control subjects were selected from those who were subjected to colonoscopy and their colonic mucosa were shown to be free of gastrointestinal lesions. Moreover, no gastrointestinal or major disease was found in control subjects after conducting a thorough medical examination and after retrieving their medical and surgical history. Colonoscopical biopsies were taken from control subjects for comparing them with excisional biopsies of CRC patients. CRC patients involved in this study were presented at all stages of the disease, B1 to D. Written consents were obtained from the participants. The study was carried out in the scope of Helsinki declaration of ethical principles of medical research and permission was granted from the Ethics Committee of biomedical research.

\section{Standard bacterial strains}

Three different members of SGMB which are genetically close to each other were used as positive standard bacterial strains (PSBS), namely $S$. gallolyticus subspecies gallolyticus CIP 105428 (ACM 3611), S. gallolyticus subspecies macedonicus CIP 105683, and S. gallolyticus subspecies pasteurianus CIP 105070. On the other hand, closely related taxa and dominant intestinal species of bacteria that are rarely associated with CRC were included as negative standard bacterial strains (NSBS). NSBS included S. lutetiensis strain CIP 108103, S. pyogenes strain CIP 56.41, S. equinus strain CIP 102504, S. bovis ACM 3539, Enterococcus faecalis CIP 76117, and Bacteroides fragilis ATCC 25285. PSBS and NSBS were used to double check the specificity of the already tested [39] manganese-dependent superoxide dismutase $(\operatorname{sod} A)$ gene-specific primers and $\operatorname{sod} A$ gene-specific probe at the conditions of the pursued assays of PCR and in situ hybridization (ISH), respectively. All the strains of PSBS were cultured at $37^{\circ} \mathrm{C}$ on Columbia blood agar (Oxoid Ltd., UK) with $5 \%$ horse blood while
NSBS bacteria were cultured according to the corresponding media for each species.

\section{Specimens of colorectal mucosa and tumors}

The excisional biopsies of tumor lesions that were taken from CRC patients after surgery and the colonoscopy punch biopsies that were taken from control group were prepared for four different processing pathways: bacteriological isolation of SGMB, DNA extraction for conventional and quantitative real-time PCR targeting DNA of SGMB, mRNA extraction for semi-quantitative realtime RT-PCR of IL-1, IL-8, IFN- $\gamma$, COX-2, c-Myc, and $\mathrm{Bcl}-2$, and in situ hybridization (ISH) assay for the detection of S. gallolyticus SodA gene, IL-1, IL-8, IFN- $\gamma$, COX-2, c-Myc, and Bcl-2 nucleotides. By a histopathologist, biopsies from CRC patients were categorized into 2 groups, tumorous, TU, (from tumor lesion itself) and non-tumorous, NTU, (from histologically tumor-free resection margins). In addition, fecal samples were collected from control subjects as well as from CRC patients preoperatively for assessing and enumerating fecal S. gallolyticus/bovis bacteria.

\section{Isolation of SGMB}

SGMB were subjected for isolation from fecal material and colorectal tissues. The isolation and differentiation of target bacteria were based on the protocols of Devriese et al. [12]. For the bacteriological tests, terms like S. gallolyticus and S. bovis were used rather than SGMB because, by using bacteriological tests, it is difficult to differentiate target bacteria into the molecular-based new terminology used in this study. However, by using API biochemical tests, bacteriologically-proven S. gallolyticus were shown to cover SGMB, namely S. bovis I and II/2, or S. gallolyticus gallolyticus and S. gallolyticus pasterianus, while bacteriologically-proven $S$. bovis were shown to represent non-SGMB family, more precisely S. bovis biotype II/1 or S. infantarius bacteria. For the preparation of specimens, $5 \mathrm{~g}$ of feces were 1:5 diluted in brain heart infusion broth (Oxoid, UK) with $5 \%$ bovine blood (Oxoid, UK) for $18-24 \mathrm{~h}$ at $37^{\circ} \mathrm{C}$. For colorectal tissues, $5 \mathrm{~g}$ were rinsed thoroughly with shaking for $5 \mathrm{~min}$ in $30 \mathrm{ml}$ of PBS for the recovery of mucosally attached target bacteria and PBS was then centrifuged at $3,000 \times \mathrm{g}$ for $5 \mathrm{~min}$ at $15^{\circ} \mathrm{C}$. The pellet was then resuspended in $1 \mathrm{ml}$ of brain heart infusion broth and Columbia agar with $5 \%$ bovine blood for $18-24 \mathrm{~h}$ at $37^{\circ} \mathrm{C}$. On the other hand, for bacteria infiltrating colorectal tissues, the rinsed colorectal tissues ( $5 \mathrm{~g}$ ) were washed thoroughly three times with PBS to get rid of any remaining surface bacteria and were then homogenized mechanically and incubated in brain heart infusion broth and Columbia agar with $5 \%$ bovine blood for $18-24 \mathrm{~h}$ at $37^{\circ} \mathrm{C}$. Enriched bacteria were then grown on 
two selective media, Slantez and Bartley agar (Oxoid, UK) and Edwards agar with $5 \%$ bovine blood (Oxoid, UK) at $42^{\circ} \mathrm{C}$; plates were incubated in air and supplemented with $5 \% \mathrm{CO}_{2}$ which increased growth of all strains. S. gallolyticus was differentiated from S. bovis in selective media by colony morphology and color [12]. In Slantez Bartley medium, dark red colonies were diagnosed as Enterococcus, small white colonies as S. bovis, and small pale pink colony as S. gallolyticus. For Edwards agar, S. gallolyticus, unlike S. bovis, was grown without brown-black discoloration. In addition, for confirming the identity of target bacteria in terms of S. bovis I, II/1, or II/2, API 20, Strep and Rapid ID32 Strep galleries (BioMérieux, La Balme les Grottes, France) were used. Moreover, solution of $6.5 \% \mathrm{NaCl}$ was also used for salt tolerance [12].

\section{DNA and RNA extraction of colorectal biopsies}

DNA extraction was done according to the instructions of TRI-zol kit (invitrogen, USA) which is a modification of Guanidium Isothiocyanate method. First, a piece of colorectal tissue was put in a tube containing $300 \mu \mathrm{l}$ Tri-Zol solution. The tissue was minced using the tip of a pointed pincet then vortexed for 1 minute. The tube was left for $5 \mathrm{~min}$ at room temperature. Into the tube, $80 \mu \mathrm{l}$ of chloroform (Merck, Germany) were added. For DNA isolation, the organic phase was then pipetted into a new tube containing $200 \mu \mathrm{l}$ of protein precipitation solution (Promega, USA) to purify the genomic DNA and the resulting reaction mixture was vigorously vortexed for $20 \mathrm{~s}$. Afterwards, the mixture was incubated in ice for $5 \mathrm{~min}$, and centrifuged at 13,000 $\times g$ for $3 \mathrm{~min}$ at $4^{\circ} \mathrm{C}$. The supernatant was carefully transferred into a clean $1.5 \mathrm{ml}$ microcentrifuge tube containing $200 \mu \mathrm{l}$ of absolute ethanol. The tube was shaken and left for $1 \mathrm{~h}$ in $2-8^{\circ} \mathrm{C}$. DNA was sedimented by centrifuging in 8,000 $\times \mathrm{g}$ for $10 \mathrm{~min}$ at $4{ }^{\circ} \mathrm{C}$ and was washed twice using $75 \%$ ethanol (Merck, Germany). It was dried for $30 \mathrm{~min}$ at room temperature. DNA was suspended using $100 \mu \mathrm{l}$ DNA rehydration solution (Promega, USA) $[40,41]$. DNA yield was 10 to $12 \mu \mathrm{g}$; the absorbance ratio of 260/280 nm was > 1.8 and DNA quality was assessed further by gel electrophoresis. For RNA isolation, the aqueous part was removed to a Rnase-free $1.5 \mathrm{ml}$ microcentrifuge Tube (Invitrogen, USA) and RNA was precipitated by adding $0.5 \times$ volume of $100 \%$ room temperature ethanol [42]. Then, RNA was purified by using QIAGEN RNeasy Mini Kit (QIAGEN, Germany); the procedure was conducted according to the protocol outlined in the RNeasy Mini Handbook [43]. Average RNA yield was 4 to $6 \mu \mathrm{g}$ and absorbance ratio of 260/ $280 \mathrm{~nm}$ was $>1.8$. RNA quality was assessed using Agilent 2100 Bioanalyzer with RNA LabChip kit (Agilent, USA).

\section{DNA extraction of standard bacteria}

DNA of the standard bacteria was extracted using Wizard ${ }^{\bullet}$ Genomic DNA Purification Kit with accessory reagents (Promega, USA); the method of extraction was done according to the manufacturer's instructions. The obtained genomic DNA was re-hydrated by adding 100 $\mu$ I DNA Rehydration solution. Extracted DNA 260/280 $\mathrm{nm}$ ratio was $>1.8$ and quality was assessed by gel electrophoresis.

\section{The specificity of SodA gene primers}

The primers designed for the current study were used in both conventional and quantitative real-time PCR for the detection of SGMB DNA. The forward primer, $\mathbf{5}^{\prime}$ CAATGACAATTCACCATGA-3', is composed of 19 bases whereas the reverse primer, $\mathbf{5}^{\prime}$-TTGGTGCTTT TCCTTGTG-3', is composed of 18 bases. These primers were already tested by a previous study [39] by which these primers were shown to be highly specific in targeting $\operatorname{Sod} A$ gene for the identification of 23 strains of SGMB including S. gallolyticus, S. pasteurianus and S. macedonicus strains while these primers were shown to be negative for $S$. infantarius, $S$. salivarius, and $S$. equines [39]. Because these primers were first designed in 2004 and gene bank is expanding progressively every year, the specificity of these primers was rechecked by our team in 2008 and 2009 using Genbank BLAST-Primer program which reconfirmed that these primers are highly specific for SGMB DNA. The nucleotide sequences of sodA gene in S. gallolyticus subspecies gallolyticus, S. gallolyticus subspecies pasterianus, and $S$. gallolyticus subspecies macedonicus were the only sequences showing complete complimentarity with the tested primers yielding a product of $408 \mathrm{bp}, \mathrm{Tm} 84.4 \mathrm{C}$, and GC content $44.3 \%$. The accession numbers of nucleotide sequences that showed complete complimentarity were: FJ617234, FJ617229, FJ617228, FJ042703, FJ151363, FJ151362, FJ151361, FJ151360, FJ151359, FJ151357, FJ151355, DQ232583, DQ232578, DQ232549, AY035715, AY035714, AJ297211, AJ297209, AJ297208, AJ297206, AJ297204, AJ297202, AJ297201, AJ297200, AJ297199, AJ297198, AJ297197, AJ297196, AJ297195, AJ297193, AJ297192, AJ297191, AJ297190, AJ297183, FJ617226, FJ151367, and AY315154. Other strains and species, including homo sapiens, were non-complimentary to the tested primers.

In the current study, for more confirmation, the $\operatorname{sod} A$ gene primers were tested on PSBS that are supposed to be recognized by these primers and NSBS that are not supposed to be recognized by these primers by using conventional PCR assay on DNA extracted from PSBS and NSBS via Wizard ${ }^{\circ}$ Genomic DNA Purification Kit. Moreover, to simulate DNA extracted from colorectal tissues, SodA gene primers were tested on DNA 
extracted from PSBS or NSBS-inoculated colorectal tissue biopsies of control group via TRI-zol kit, which were named PSBS-tissue and NSBS-tissue, respectively.

\section{Conventional PCR for bacterial sodA gene}

The PCR protocol used was based on a previous study [39] with modifications applied after frequent optimization runs. Two $\mu \mathrm{l}$, in duplicates, of DNA extracted from PSBS and NSBS, DNA extracted from PSBS-tissue and NSBS-tissue, and DNA extracted from colorectal tissues of CRC and control subjects were added to the PCR master mixture, which consisted of $2 \mu \mathrm{l}$ of $10 \times$ PCR buffer, $0.8 \mu \mathrm{l}$ of a $10 \mathrm{mM}$ deoxynucleoside triphosphate mixture, $0.7 \mu \mathrm{l}$ of forward and reverse primers at concentration of $10 \mathrm{pmol} / \mu \mathrm{l}, 1.5 \mu \mathrm{l}$ of $25 \mathrm{mM} \mathrm{MgCl}_{2}$, and $0.2 \mu \mathrm{l}$ of $0.5 \mathrm{U}$ Taq DNA polymerase; the remaining volume consisted of distilled water. All the reaction mixtures were obtained from (Promega, USA). The reaction mixture in microcentrifuge tube was amplified in a thermocycler PCR system (PTC-110TM Model, MJ Research, Inc., USA). The PCR protocol consisted of an initial denaturation at $95^{\circ} \mathrm{C}$ for 5 min with 30 cycles of denaturation at $94^{\circ} \mathrm{C}$ for $60 \mathrm{~s}$, annealing at $52^{\circ} \mathrm{C}$ for $30 \mathrm{~s}$, and extension at $72^{\circ} \mathrm{C}$ for $30 \mathrm{~s}$; and a final extension at $72^{\circ} \mathrm{C}$ for $8 \mathrm{~min}$. Afterwards, $5 \mu \mathrm{l}$ of PCR products were electrophoresed on $2 \%$ agarose gel using QIAGEN GelPilot DNA Molecular Weight (Qiagen, Germany) as a ladder. PCR products were separated by an electrophoresis system at a constant voltage of $80 \mathrm{~V}$ for $50 \mathrm{~min}$ and were stained with $0.25 \mu \mathrm{g} / \mathrm{ml}$ ethidium bromide (Sigma, USA). PCR products were photographed under UV transilluminator (Vilber Lourmat, Cedex, France) and the photos were taken using gel documentation system, Bio Rad Gel Doc 2000 Model Imaging System (Bio-Rad, USA). PCR assay yielded an amplicon of $408 \mathrm{bp}$. Positive control, in duplicate, was included containing DNA from reference S. gallolyticus subsp. gallolyticus CIP105428, whereas negative control, in duplicate, was included containing all PCR reactive agents except for template DNA.

\section{Standard curve of real-time PCR}

The purified PCR product of interest, $408 \mathrm{bp}$, obtained from streptococcus gallolyticus subsp. gallolyticus CIP105428 was ligated into pGEM $^{\circledR}$-T Easy Vector (Promega, USA) which consisted of a mixture of $2 \times$ rapid ligation buffer, pGEMTR Easy Vector, purified PCR product, T4 DNA ligase and sterile distilled water. Escherichia coli competent cells of strain JM 109 were used to carry pGEM-T Easy Vector (Promega, USA). The plasmid DNA along with PCR product insert was then extracted according to the manufacturer's instructions using Wizard ${ }^{\circ}$ Plus SV Minipreps (Promega, USA). The initial concentration of the plasmid DNA of interest was
$8.3 \mu \mathrm{g} / \mathrm{ml}$. The plasmid with the correct insert was then 10 -fold serially diluted up to 8 dilutions. Since the molecular weight of the plasmid DNA is known, the concentration of these dilutions were then transformed into log copy number $(\log \mathrm{CN})$, defined as SGMB load, which was plotted against the threshold cycle $(\mathrm{Ct})$ to generate the standard curve used for the absolute quantification by real-time PCR. Moreover, the plasmid DNA of interest was used as positive control while the negative control was managed to be devoid of template DNA.

\section{Quantitative real-time PCR for bacterial sodA gene}

For quantitative assessment of SGMB load in colorectal tumor biopsies, absolute quantitative real-time PCR was designed using the same sodA gene primers used in the conventional PCR with modifications. Real-time PCR amplification reaction was performed with Rotor-GeneTM 3000 (Corbett. Research, Australia) using fluorescent dye SYBR Green (QiagenTM QuantiTect ${ }^{\circ}$ SYBR Green PCR kit). The reaction was performed in a total volume of $25 \mu \mathrm{l}(2.5 \mu \mathrm{l}$ of $10 \times$ PCR buffer); the composition of the reaction mixture per sample was as follows: $1.8 \mu \mathrm{l}$ of $25 \mathrm{mM} \mathrm{MgCl} 2,0.7 \mu \mathrm{l}$ of $10 \mathrm{mM}$ dNTP, $9.5 \mu \mathrm{l}$ SYBR Green, $1.5 \mu \mathrm{l}$ of $25 \mu \mathrm{M}$ reverse and forward primers, $0.125 \mu \mathrm{l}$ of $5 \mathrm{U} / \mu \mathrm{l}$ Taq DNA polymerase, $5.0 \mu \mathrm{l}$ DNA template $(\sim 16 \mathrm{ng})$, and the rest was RNase free water. All the reaction mixtures were obtained from Promega (Promega, USA). PCR protocol consisted of an initial denaturation at $95^{\circ} \mathrm{C}$ for $5 \mathrm{~min} ; 35$ cycles of denaturation for $60 \mathrm{~s}$ at $94^{\circ} \mathrm{C}$, annealing for $30 \mathrm{~s}$ at $52^{\circ} \mathrm{C}$, and extension for $30 \mathrm{~s}$ at $72^{\circ} \mathrm{C}$; and a final extension cycle for $8 \mathrm{~min}$ at $72^{\circ} \mathrm{C}$. The serially diluted standards, positive and negative controls, and samples were all simultaneously assayed, in duplicates, during real-time amplification. At the end of amplification, measurement of the SYBR Green fluorescence was done continuously through conducting the melting curve analysis by slow heating at $0.2^{\circ} \mathrm{Cs}-1$ increments from 60 to $99{ }^{\circ} \mathrm{C}$, with continuous fluorescence collection. Accordingly, a melting curve was generated at the end of the PCR amplification for monitoring the specificity of PCR reaction.

\section{Semi-quantitative real-time RT PCR for IFN- $\gamma$, COX-2, IL-1,} $\mathrm{IL}-8$, c-Myc, and Bcl-2

One-step RT-PCR was used; 250 ng of RNA were reverse transcribed into cDNA for $10 \mathrm{~min}$ at $55^{\circ} \mathrm{C}$ [44]. Real-time PCR amplification reaction was performed with Rotor-GeneTM 3000 (Corbett. Research, Australia) using fluorescent dye SYBR Green (QiagenTM QuantiTect $^{\circ}$ SYBR Green PCR kit). Gel electrophoresis and melting curve analysis at $0.2^{\circ} \mathrm{Cs}-1$ increments from 60 to $99^{\circ} \mathrm{C}$ were used for confirming reaction specificity. Human $\beta$-actin mRNA was used as an internal control. Amplification was done in a volume of $20 \mu \mathrm{l}$ for 
Table 6 Details of the primers used for the amplification of IL-1, IFN- $\gamma$, COX-2, IL-8, c-Myc, and Bcl-2 with the corresponding targets and PCR conditions

\begin{tabular}{|c|c|c|c|c|}
\hline Target & Primer sequence & PCR conditions & Manufacturer & Reference \\
\hline $\begin{array}{l}\beta \text {-actin for } \mathrm{COX}-2, \mathrm{IL}-1 \beta, \mathrm{IL}-8, \\
\text { and } \mathrm{BCl}-2\end{array}$ & $\begin{array}{l}\text { F-5'-GATGAGATTGGCATGGCTTT-3' } \\
\text { R-5'-CACCTTCACCGTTCCAGTTT-3' }\end{array}$ & $15 \mathrm{~s} 95^{\circ} \mathrm{C}, 20 \mathrm{~s} 60^{\circ} \mathrm{C}, 60 \mathrm{~s} 72^{\circ} \mathrm{C}$ & $\begin{array}{l}\text { Maximbio, } \\
\text { USA }\end{array}$ & [48] \\
\hline $\operatorname{cox}-2$ & $\begin{array}{l}\text { F-5'-TCCTATTATACTAGAGCCCTTCCT- } \\
3^{\prime} \\
\text { R-5'-TTCCACAATCTCATTTGAATCAGG- } \\
3^{\prime} .\end{array}$ & $15 \mathrm{~s} 95^{\circ} \mathrm{C}, 20 \mathrm{~s} 60^{\circ} \mathrm{C}, 30 \mathrm{~s} 72^{\circ} \mathrm{C}$ & $\begin{array}{l}\text { Maximbio, } \\
\text { USA }\end{array}$ & [48] \\
\hline$\| \mathrm{L}-1 \beta$ & $\begin{array}{l}\text { F, 5'-TCCAGGGACAGGATATGGAG-3', } \\
\text { R, 5'-TCTTCAACACGCAGGACAG-3' } \\
\text { (133 bp); }\end{array}$ & $20 \mathrm{~s} 95^{\circ} \mathrm{C}, 60 \mathrm{~s} 60^{\circ} \mathrm{C}, 30 \mathrm{~s} 72 \mathrm{~s}$ & Promega, & [49] \\
\hline IL-8 & $\begin{array}{l}\text { F-TAGCAAAATTGAGGCCAAGG } \\
\text { R-GGACTTGTGGATCCTGGCTA }\end{array}$ & $20 \mathrm{~s} 95^{\circ} \mathrm{C}, 60 \mathrm{~s} 60^{\circ} \mathrm{C}, 30 \mathrm{~s} 72 \mathrm{~s}$ & $\begin{array}{l}\text { DNASTAR, } \\
\text { USA }\end{array}$ & [50] \\
\hline $\mathrm{BCl}-2$ & $\begin{array}{l}\text { F-5'acatcgccctgtggatgact3' } \\
\text { R-5'gggecgtacagttccacaaa3 }\end{array}$ & $\begin{array}{l}95^{\circ} \mathrm{C} 3 \mathrm{~min}, 40 \text { cycles } 95^{\circ} \mathrm{C} 30 \mathrm{~s}, 58^{\circ} \mathrm{C} 30 \mathrm{~s}, \\
\text { and } 73^{\circ} \mathrm{C} 30 \mathrm{~s}\end{array}$ & Promega, USA & [51] \\
\hline$\beta$-actin for IFN- $\gamma$ and $c-M y c$ & $\begin{array}{l}\text { F-5'-GATGGCCACGGCTGCTT-3' } \\
\text { R-5'-ACCCTCATTGCCAATGGT-3' }\end{array}$ & $20 \mathrm{~s} 95^{\circ} \mathrm{C}$, annealing/extension $60 \mathrm{~s} 60^{\circ} \mathrm{C}$ & $\begin{array}{l}\text { Maximbio, } \\
\text { USA }\end{array}$ & [52] \\
\hline $\mathrm{IFN}-\gamma$ & $\begin{array}{l}\text { F-5'-CAGCTCTGCATCGTTTTGGG-3' } \\
\text { R-5'-GTTCCATTATCCGCTACATCTGAA- } \\
3^{\prime}\end{array}$ & $20 \mathrm{~s} 95^{\circ} \mathrm{C}$, annealing/extension $60 \mathrm{~s} 60^{\circ} \mathrm{C}$ & $\begin{array}{l}\text { DNASTAR, } \\
\text { USA }\end{array}$ & [52] \\
\hline c-Myc & $\begin{array}{l}\text { F-TCAAGAGGTGCCACGTCTCC } \\
\text { R-TCTTGGCAGCAGGATAGTCCTT }\end{array}$ & $30 \mathrm{~s} 95^{\circ} \mathrm{C}, 70 \mathrm{~s} 60^{\circ} \mathrm{C}$ (annealing/extension). & $\begin{array}{l}\text { Maximbio, } \\
\text { USA }\end{array}$ & [50] \\
\hline
\end{tabular}

40 cycles with preliminary 10 min denaturation phase at $95^{\circ} \mathrm{C}$ and a final $72^{\circ} \mathrm{C}$ extension phase for $8 \mathrm{~min}$. The manufacturers and sequences of the used primers together with the corresponding PCR protocols are shown in Table 6. The mRNA expression of target or reference samples was normalized to the mRNA expression of the corresponding human $\beta$-actin. The relative expression of the studied mRNA molecules was determined by relating the normalized expression of each target, in duplicates, to the normalized expression of a reference sample to calculate a fold-change value in term of mRNA ratio. Positive controls of the studied targets were supplied by the primers' manufacturers and were all tested to yield consistent positive results whereas the negative controls were those samples prepared without DNA template.

\section{Probes used for in situ hybridization assay}

For the detection of SodA gene DNA via ISH assay, SodA gene-specific biotinylated probe was designed according to the nucleotide sequence accession no. AJ297183 by using megablast and discontiguous megablast algorithms for alignment similarity (GenBank, BLAST). The probe size is 435 bp of linear DNA targeted for $\operatorname{sodA}$ gene of superoxide dismutase of S. gallolyticus subspecies gallolyticus (strain CIP 105428T, ACM 3611). This probe was named as S.g-sodA probe. It was synthesized and biotinylated by (Promega laboratories, USA). S.g-sodA probe was designed to be highly specific for S. gallolyticus subspecis gallolyticus, $S$. gallolyticus subspecis pasteurianus, and $S$. gallolyticus subspecies macedonicus while it was designed to be incompatible with other related taxa of bacteria, or other organisms' genomes including Homo sapiens. This design is necessary to avoid mispriming with DNA of other bacteria or of huamn colroectal tissues. For more confimration, the specificity of S.gsodA probe was assessed by our team by using ISH assay on duplicates of three strains of PSBS-tissue and six srtains of NSBS-tissue sections at identical conditions to these used for test sections. The strains of PSBS-tissues were CIP 105428, CIP 105683, and CIP 105070 while the strains of NSBS-tissues were CIP 108103, CIP 56.41, CIP 102504, ACM 3539, CIP 76117, and ATCC 25285.

For the mRNA detection of targeted cytokines and oncogenes via ISH assay, biotinylated long cDNA probes were used including human mRNA of IFN- $\gamma$ (MaxHyb Probe, human IFN- $\gamma$, PB-60088, probe size 423 bp, GenBank Accession No: NM_000619, Maximbio, USA), COX-2 (MaxHyb Probe, human COX2, PB-60161, probe size 278 bp, GenBank Accession No: BC013734, Maximbio, USA), Bcl-2 (MaxHyb Probe, human Bcl-2, PB-60010, probe size 235 bp, GenBank Accession No: M14745, maximbio, USA), c-Myc (MaxHyb Probe, human c-Myc, PB-60052, probe size 1181, GenBank Accession No: V00568, Maximbio, USA), IL-1 $\beta$ (MaxHyb Probe, human IL-1 $\beta$, PB-60089, probe size 196 bp, Genbank accession no. NM_000576, Maximbio, USA), and IL-8 ((MaxHyb Probe, human Interleukin 8, PB60092, probe size $299 \mathrm{bp}$, Genbank accession no. NM_000584, Maximbio, USA). 

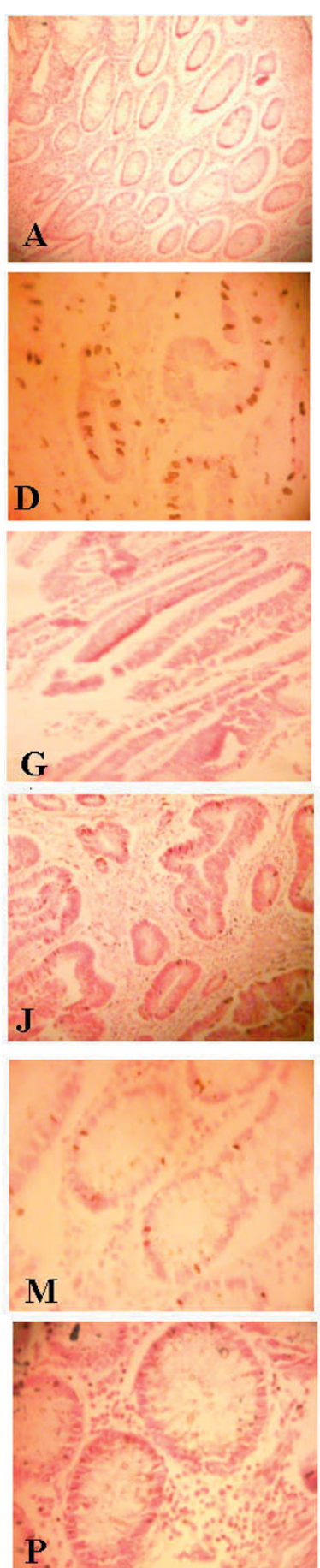
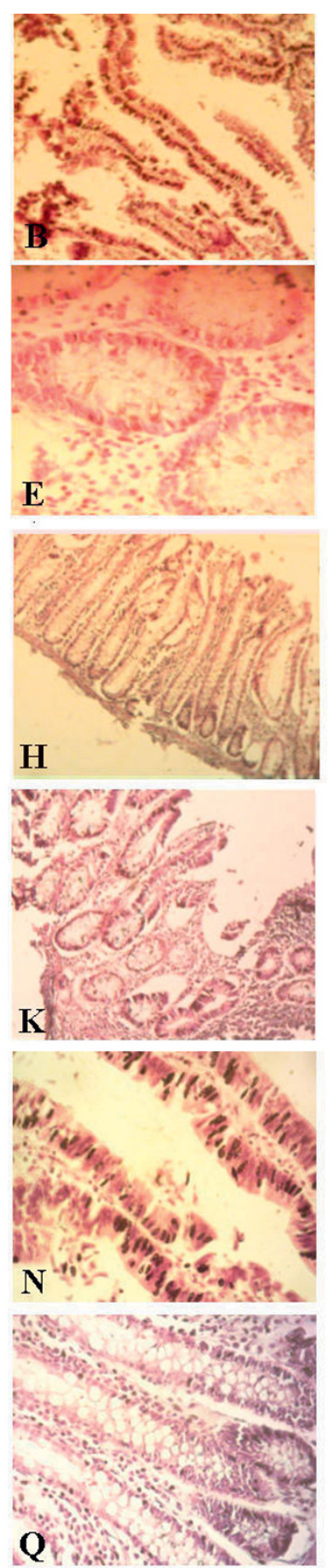

Figure 5 Examples of ISH staining of mRNA of IL-1, IFN- $\boldsymbol{\gamma}$, COX-2, IL-8, c-Myc, and Bcl-2. Cells stained positive are shown with dark color of NBT/BCIP in the nuclei of glandular cells as well as stromal cells. mRNA expression of IL-1 (A-C) at X100, IFN- $\gamma$ (D-F) at 400X, COX-2 (G-I) at X100, and IL-8 (J-L) at 100X, is shown in control, TU SGMB+ve-CRCW/bac, and TU SGMB-ve-CRC-W/bac, respectively. mRNA expression of C-Myc (M-O) at X400 and Bcl-2 (P-R) at X400 is shown in control, TU SGMB-ve-CRC-wo/bac, and NTU SGMB-ve-CRC-wo/bac.

In situ hybridization for SodA gene, IFN- $\gamma$, COX-2, IL-1, IL-8, c-Myc, and Bcl-2

Proper histopathological processing necessitated several steps to be pursued by the pathologist to minimize the
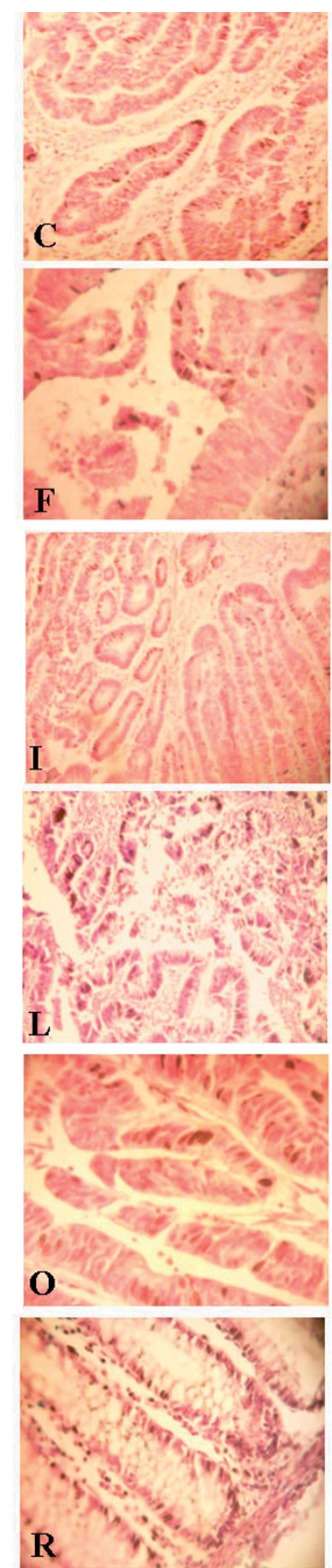

fixation-associated loss of mRNA including minimal prefixation time, up to one hour, using cold $4 \%$ paraformaldehyde, cold fixation at $4{ }^{\circ} \mathrm{C}$, and short duration of fixation, up to $5 \mathrm{~h}$ [45]. Paraffin-embedded sections were 
processed for ISH assay within 3 days before the examination because it was reported that no remarkable loss of nucleic acids is found in the first three days of fixation and paraffin embedding [46]. Histopathological paraffin blocks, whether for CRC patients or control subjects, were processed into sections of 4 um thickness. From both TU and NTU tissues, numerous histopathological sections were made for each CRC patient. Hematoxylin and Eosin slides were prepared by the pathologist to confirm the histopathological diagnosis and the grading of CRC. One negative control tissue section was used at every run of ISH by using diluent buffer instead of probes. In addition, a consistently and strongly positive section was used as positive control along with one endogenous positive probe control. The procedure was pursued according to "DNA probe Hybridization/Detection System - in situ Kit" (Maximbio, USA) with some modifications according to Abdulamir et al [16].

\section{Staining analysis}

For mRNA expression of the studied cytokines, chemokines, and oncogenes, the percentage of stained glandular and stromal cells with blue/black nuclear staining was calculated out of total cells in 5 high power fields. Regarding IFN- $\gamma$, IL-1, IL-8, COX-2, c-Myc, and Bcl-2, many scoring systems, sometimes contradicting, were found; however, to keep solid comparative basis among the studied groups and to compare ISH results with that of the semi-quantitative real-time RT-PCR, no certain scoring system was used. Instead, the percentage of the positively stained cells out of total cells was used; examples of ISH mRNA staining are shown in Figure 5. On the other hand, stained SGMB DNA appeared as chains of dark tiny spots scattered throughout the examined sections representing the colonizing SGMB; examples of
ISH staining of SGMB DNA are shown in Figure 6. The interpretation of ISH staining by S.g-sodA probe was assessed qualitatively. Since the presence of SGMB DNA in colorectal tissues is considered abnormal, any positive detection of SGMB DNA was considered positive.

\section{Statistical analysis}

Statistical analysis was conducted using SPSS software version 14.2.1 and MS EXCEL 2007. The normality of quantitative continuous data was tested by Kolmogorov-Smirnov test. Data in the current study were found to be normally distributed; therefore, quantitative data were expressed in mean \pm SEM and, therefore, parametric tests were used. Depending on F-test for variance, univariate and multivariate student $t$-test were used for measuring the significance of difference between two means. Categorized qualitative (frequency) data were treated by chi square for independence or Fisher's exact test, when needed, for measuring the significance of association among different studied groups. Moreover, Pearson correlation coefficient ( $r$ ) was used along with ANOVA test for assessing the significance of correlation. For SGMB cell count, or SGMB load, in colorectal tissues, it was transformed into logarithmic values in terms of $\log _{10}$ copy number per gram $\left(\log _{10} \mathrm{CN} /\right.$ g). The mean $\log _{10} \mathrm{CN} / \mathrm{g}$ was calculated by averaging the individual $\log _{10} \mathrm{CN} / \mathrm{g}$ values [47]. 95\% confidence interval (CI) of mean $\log _{10} \mathrm{CN} / \mathrm{g}$ was used to express uncertainty measurements of bacterial counts and to measure the significance of difference among different groups. $P$ values $<0.05$ were considered significant.

\section{List of abbreviations}

CN: copy number; CRC: colorectal cancer; Ct: threshold cycle; CRC-w/bac: colorectal cancer with bacteremia; CRC-wo/bac: colorectal cancer without bacteremia; ISH: in situ hybridization; NSBS: negative standard bacterial; PSBS: positive standard bacterial; SGMB: streptococcus gallolyticus member
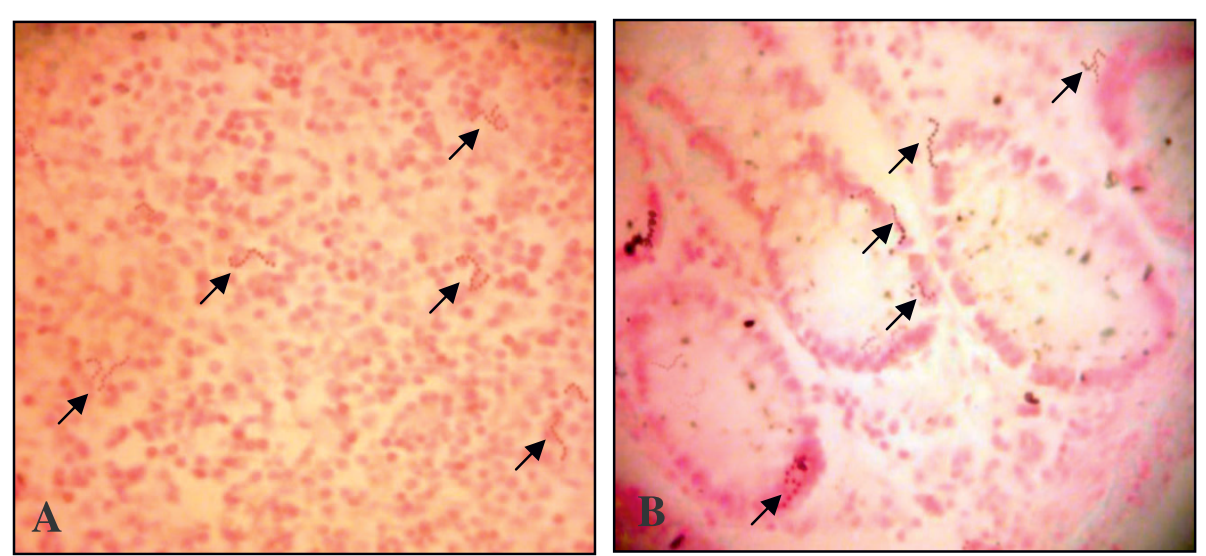

Figure 6 Examples of ISH staining of SGMB DNA at 400X in colorectal tissues of (A) TU SGMB+ve-CRC-w/bac and (B) NTU SGMB+veCRC-wo/bac. SGMB DNA staining was shown as chains of stained tiny dark spots which are pointed by black arrows. No distinctive pattern of distribution of the positively stained SGMB was seen throughout stained sections. 
bacteria; SGMB+ve: SGMB positive; SGMB-ve: SGMB negative; sodA: superoxide dismutase $A$; TU: tumorous; NTU: non-tumorous.

\section{Competing interests}

The authors of the current manuscript confirm that there is no any kind of competing interests.

\section{Authors' contributions}

All authors read and approved the final manuscript. AS and RR did sampling of specimens, RR performed the bacteriological assays and AS performed the molecular assays. F and AS performed tissue staining and statistical design.

\section{Acknowledgements}

This study owes much to the great assistance granted by Hospitals specialists. Special gratitude to CRC patients who participated in this study as well as control volunteers who shared their time with us.

\section{Author details}

${ }^{1}$ Institute of Bioscience, University Putra Malaysia, 43400 Serdang, Selangor, Malaysia. ${ }^{2}$ Alnahrain University, College of Medicine, 14222, Baghdad, Iraq.

Received: 28 February 2010 Accepted: 17 September 2010 Published: 17 September 2010

\section{References}

1. Triantafillidis JK, Nasioulas G, Kosmidis PA: Colorectal cancer and inflammatory bowel disease: epidemiology, risk factors, mechanisms of carcinogenesis and prevention strategies. Anticancer Res 2009, 29(7):2727-2737

2. Ablashi DV, Chatlynne LG, Whitman JE Jr, Cesarman E: Spectrum of Kaposi's sarcoma-associated herpesvirus, or human herpesvirus 8 , diseases. Clin Microbiol Rev 2002, 15(3):439-464.

3. Boshoff C, Weiss R: AIDS-related malignancies. Nat Rev Cancer 2002, 2(5):373-382.

4. Parsonnet J: Bacterial infection as a cause of cancer. Environ Health Perspect 1995, 103(Suppl 8):263-268.

5. Malfertheiner $P$, Sipponen $P$, Naumann M, Moayyedi P, Megraud F, Xiao SD, Sugano K, Nyren O: Helicobacter pylori eradication has the potential to prevent gastric cancer: a state-of-the-art critique. Am J Gastroenterol 2005, 100(9):2100-2115.

6. Wilson WR, Thompson RL, Wilkowske CJ, Washington JA, Giuliani ER Geraci JE: Short-term therapy for streptococcal infective endocarditis. Combined intramuscular administration of penicillin and streptomycin. JAMA 1981, 245(4):360-363.

7. Reynolds JG, Silva E, McCormack WM: Association of Streptococcus bovis bacteremia with bowel disease. J Clin Microbiol 1983, 17(4):696-697.

8. Leport C, Bure A, Leport J, Vilde JL: Incidence of colonic lesions in Streptococcus bovis and enterococcal endocarditis. Lancet 1987, 1(8535):748

9. Zarkin BA, Lillemoe KD, Cameron JL, Effron PN, Magnuson TH, Pitt HA: The triad of Streptococcus bovis bacteremia, colonic pathology, and liver disease. Ann Surg 1990, 211(6):786-791, discussion 791-782

10. Murray PR, Baron EJ: Manual of clinical microbiology ASM Press, Washington, D.C, USA 2007.

11. Osawa R, Fujisawa T, Sly LI: Streptococcus gallolyticus sp. nov.: gallate degrading organisms formerly assigned to Streptococcus bovis. Syst Appl Microbiol 1995, 18:74-78.

12. Devriese LA, Vandamme P, Pot B, Vanrobaeys M, Kersters K, Haesebrouck F: Differentiation between Streptococcus gallolyticus strains of human clinical and veterinary origins and Streptococcus bovis strains from the intestinal tracts of ruminants. J Clin Microbiol 1998, 36(12):3520-3523.

13. Schlegel L, Grimont F, Ageron E, Grimont PA, Bouvet A: Reappraisal of the taxonomy of the Streptococcus bovis/Streptococcus equinus complex and related species: description of Streptococcus gallolyticus subsp. gallolyticus subsp. nov., S. gallolyticus subsp. macedonicus subsp. nov. and S. gallolyticus subsp. pasteurianus subsp. nov. Int J Syst Evol Microbiol 2003, 53(Pt 3):631-645.

14. Lee RA, Woo PC, To AP, Lau SK, Wong SS, Yuen KY: Geographical difference of disease association in Streptococcus bovis bacteraemia. J Med Microbiol 2003, 52:903-908.
15. Jean SS, Teng LJ, Hsueh PR, Ho SW, Luh KT: Bacteremic Streptococcus bovis infections at a university hospital, 1992-2001. J Formos Med Assoc 2004, 103:118-123.

16. Abdulamir AS, Hafidh RR, Mahdi LK, Al-jeboori T, Abubaker F: Investigation into the controversial association of Streptococcus gallolyticus with colorectal cancer and adenoma. BMC Cancer 2009, 9:403.

17. Beck M, Frodl R, Funke G: Comprehensive study of strains previously designated Streptococcus bovis consecutively isolated from human blood cultures and emended description of Streptococcus gallolyticus and Streptococcus infantarius subsp. coli. J Clin Microbiol 2008, 46:2966-2972

18. Corredoira J, Alonso MP, Coira A, Casariego E, Arias C, Alonso D, Pita J, Rodriguez A, Lopez MJ, Varela J: Characteristics of Streptococcus bovis endocarditis and its differences with Streptococcus viridans endocarditis. Eur J Clin Microbiol Infect Dis 2008, 27:285-291.

19. Ellmerich S, Scholler M, Duranton B, Gosse F, Galluser M, Klein JP, Raul F: Promotion of intestinal carcinogenesis by Streptococcus bovis. Carcinogenesis 2000, 21(4):753-756.

20. Biarc J, Nguyen IS, Pini A, Gosse F, Richert S, Thierse D, Van Dorsselaer A, Leize-Wagner E, Raul F, Klein JP, Scholler-Guinard M: Carcinogenic properties of proteins with pro-inflammatory activity from Streptococcus infantarius (formerly S.bovis). Carcinogenesis 2004, 25(8):1477-1484.

21. Wentling GK, Metzger PP, Dozois EJ, Chua HK, Krishna M: Unusual bacterial infections and colorectal carcinoma-Streptococcus bovis and Clostridium septicum: report of three cases. Dis Colon Rectum 2006, 49(8):1223-1227

22. Rochlitz CF, Herrmann R, de Kant E: Overexpression and amplification of c-myc during progression of human colorectal cancer. Oncology 1996, 53(6):448-454.

23. Manne U, Myers RB, Moron C, Poczatek RB, Dillard S, Weiss H, Brown D, Srivastava S, Grizzle WE: Prognostic significance of $\mathrm{Bcl}-2$ expression and p53 nuclear accumulation in colorectal adenocarcinoma. Int J Cancer 1997, 74(3):346-358.

24. Burns CA, McCaughey R, Lauter CB: The association of Streptococcus bovis fecal carriage and colon neoplasia: possible relationship with polyps and their premalignant potential. Am J Gastroenterol 1985, 80(1):42-46.

25. Beeching NJ, Christmas TI, Ellis-Pegler RB, Nicholson GI: Streptococcus bovis bacteraemia requires rigorous exclusion of colonic neoplasia and endocarditis. Q J Med 1985, 56(220):439-450.

26. Norfleet RG, Mitchell PD: Streptococcus bovis does not selectively colonise colorectal cancer and rectal polyps. J Clin Gastroenterol 1993, 17:25-28.

27. Potter MA, Cunliffe NA, Smith M, Miles RS, Flapan AD, Dunlop MG: A prospective controlled study of the association of Streptococcus bovis with colorectal carcinoma. J Clin Pathol 1998, 51(6):473-474.

28. Klein RS, Recco RA, Catalano MT, Edberg SC, Casey Jl, Steigbigel NH: Association of Streptococcus bovis with carcinoma of the colon. $N$ Engl $J$ Med 1977, 297(15):800-802

29. Tjalsma H, Scholler-Guinard M, Lasonder E, Ruers TJ, Willems HL, Swinkels DW: Profiling the humoral immune response in colon cancer patients: diagnostic antigens from Streptococcus bovis. Int J Cancer 2006, 119(9):2127-2135.

30. Kaplan MH, Chmel H, Stephens A, Hsieh HC, Tenenbaum MJ, Rothenberg IR, Joachim GR: Humoral reactions in human endocarditis due to Streptococcus bovis: evidence for a common S bovis antigen. J Infect Dis 1983, 148(2):266-274.

31. Boleij A, Schaeps RM, de Kleijn S, Hermans PW, Glaser P, Pancholi V, Swinkels DW, Tjalsma $\mathrm{H}$ : Surface-exposed histone-like protein a modulates adherence of Streptococcus gallolyticus to colon adenocarcinoma cells. Infect Immun 2009, 77(12):5519-5527.

32. Sillanpaa J, Nallapareddy SR, Singh KV, Ferraro MJ, Murray BE: Adherence characteristics of endocarditis-derived Streptococcus gallolyticus ssp. gallolyticus (Streptococcus bovis biotype I) isolates to host extracellular matrix proteins. FEMS Microbiol Lett 2008, 289(1):104-109.

33. Ellmerich S, Djouder N, Scholler M, Klein JP: Production of cytokines by monocytes, epithelial and endothelial cells activated by Streptococcus bovis. Cytokine 2000, 12(1):26-31.

34. Janeway C: Immunobiology: the immune system in health and disease Garland Science, New York, USA 2005. 
35. Ohshima $\mathrm{H}$, Bartsch $\mathrm{H}$ : Chronic infections and inflammatory processes as cancer risk factors: possible role of nitric oxide in carcinogenesis. Mutat Res 1994, 305(2):253-264.

36. Jung HC, Eckmann L, Yang SK, Panja A, Fierer J, Morzycka-Wroblewska E, Kagnoff MF: A distinct array of proinflammatory cytokines is expressed in human colon epithelial cells in response to bacterial invasion. $J$ Clin Invest 1995, 95(1):55-65.

37. Mahida YR, Makh S, Hyde S, Gray T, Borriello SP: Effect of Clostridium difficile toxin $A$ on human intestinal epithelial cells: induction of interleukin 8 production and apoptosis after cell detachment. Gut 1996, 38(3):337-347.

38. Spehlmann ME, Eckmann L: Nuclear factor-kappa B in intestinal protection and destruction. Curr Opin Gastroenterol 2009, 25(2):92-99.

39. Sasaki E, Osawa R, Nishitani Y, Whiley RA: Development of a diagnostic $\mathrm{PCR}$ assay targeting the Mn-dependent superoxide dismutase gene (sodA) for identification of Streptococcus gallolyticus. J Clin Microbiol 2004, 42(3):1360-1362.

40. Chomczynski P, Mackey K: Short technical report. Modification of the TRIZOL reagent procedure for isolation of RNA from Polysaccharide-and proteoglycan-rich sources. Biotechniques 1995, 19:942-5.

41. TRIzol $^{-}$Reagent and TRIzol ${ }^{\circledR}$ LS Reagent. DNA Isolation using TRIzol. 16-20[http://vre.upei.ca/mhl/system/files/Trizol.pdf].

42. Chomczynski P, Bowser-Finn R, Sabatini L: A reagent for the single-step isolation of viral RNA from human serum and biopsy samples. J NIH Res 1994, 6:83.

43. "RNeasy Mini Handbook; RNeasy Mini Protocol for RNA Clean-up,". 79-81 [http://www.qiagen.com/literature/rnalit.asp\#mini].

44. Schostak M, Krause H, Miller K, Schrader M, Weikert S, Christoph F, Kempkensteffen C, Kollermann J: Quantitative real-time RT-PCR of CD24 mRNA in the detection of prostate cancer. BMC Urol 2006, 6:7.

45. Srinivasan $M$, Sedmak D, Jewell $S$ : Effect of fixatives and tissue processing on the content and integrity of nucleic acids. Am J Pathol 2002, 161(6):1961-1971.

46. Lisowski AR, English ML, Opsahl AC, Bunch RT, Blomme EA: Effect of the storage period of paraffin sections on the detection of mRNAs by in situ hybridization. J Histochem Cytochem 2001, 49(7):927-928

47. Drake D: Assessment of antimicrobial activity against biofilms. Methods Enzymol 2001, 337:385-389.

48. Cui X, Yang SC, Sharma S, Heuze-Vourc'h N, Dubinett SM: IL-4 regulates COX-2 and PGE2 production in human non-small cell lung cancer. Biochem Biophys Res Commun 2006, 343(4):995-1001.

49. Welsh N, Cnop M, Kharroubi I, Bugliani M, Lupi R, Marchetti P, Eizirik DL: Is there a role for locally produced interleukin-1 in the deleterious effects of high glucose or the type 2 diabetes milieu to human pancreatic islets? Diabetes 2005, 54(11):3238-3244.

50. McLachlan JL, Sloan AJ, Smith AJ, Landini G, Cooper PR: S100 and cytokine expression in caries. Infect Immun 2004, 72(7):4102-4108.

51. Steger K, Wilhelm J, Konrad L, Stalf T, Greb R, Diemer T, Kliesch S, Bergmann $\mathrm{M}$, Weidner W: Both protamine-1 to protamine-2 mRNA ratio and $\mathrm{Bc} 2 \mathrm{mRNA}$ content in testicular spermatids and ejaculated spermatozoa discriminate between fertile and infertile men. Hum Reprod 2008, 23(1):11-16.

52. Zhang Y, Wang YL, Liu YW, Li Q, Yuan YH, Niu WY, Sun LY, Zhu ZJ, Shen ZY, Han RF: Change of peripheral blood mononuclear cells IFNgamma, IL-10, and TGF-beta1 mRNA expression levels with active human cytomegalovirus infection in orthotopic liver transplantation. Transplant Proc 2009, 41(5):1767-1769.

doi:10.1186/1476-4598-9-249

Cite this article as: Abdulamir et al:: Molecular detection, quantification, and isolation of Streptococcus gallolyticus bacteria colonizing colorectal tumors: inflammation-driven potential of carcinogenesis via IL-1, COX-2, and IL-8. Molecular Cancer 2010 9:249.

\section{Submit your next manuscript to BioMed Central and take full advantage of:}

- Convenient online submission

- Thorough peer review

- No space constraints or color figure charges

- Immediate publication on acceptance

- Inclusion in PubMed, CAS, Scopus and Google Scholar

- Research which is freely available for redistribution

Submit your manuscript at www.biomedcentral.com/submit
Ciomed Central 